\title{
A sea surface temperature reconstruction for the southern Indian Ocean trade wind belt from corals in Rodrigues Island $\left(19^{\circ} \mathrm{S}, 6^{\circ} \mathrm{E}\right)$
}

\author{
Jens Zinke ${ }^{1,2,3,4}$, Lars Reuning ${ }^{5}$, Miriam Pfeiffer ${ }^{5}$, Jasper A. Wassenburg ${ }^{6}$, Emily Hardman ${ }^{7}$, \\ Reshad Jhangeer-Khan ${ }^{7}$, Gareth R. Davies ${ }^{8}$, Curtise K. C. Ng $^{9}$, and Dick Kroon ${ }^{10}$ \\ ${ }^{1}$ Department of Environment and Agriculture, Curtin University of Technology, Kent Street, Bentley WA 6102, Australia \\ ${ }^{2}$ Division of Paleontology, Freie Universität Berlin, Malteserstrasse 74-100, 12249 Berlin, Germany \\ ${ }^{3}$ Australian Institute of Marine Science, Nedlands WA 6009, Australia \\ ${ }^{4}$ School of Geography, Archaeology and Environmental Studies, University of Witwatersrand, Johannesburg, South Africa \\ ${ }^{5}$ Geological Institute, RWTH Aachen University, Wuellnerstrasse 2, 52056 Aachen, Germany \\ ${ }^{6}$ Institute for Geosciences, Johannes Gutenberg University of Mainz, Johann-Joachim-Becher-Weg 21, \\ 55128 Mainz, Germany \\ ${ }^{7}$ SHOALS Rodrigues, Rodrigues, Mauritius \\ ${ }^{8}$ Geology \& Geochemistry, VU University Amsterdam, De Boelelaan 1085, $1081 \mathrm{HV}$ Amsterdam, the Netherlands \\ ${ }^{9}$ Department of Medical Radiation Sciences, Curtin University of Technology, Kent Street, Bentley WA 6102, Australia \\ ${ }^{10}$ University of Edinburgh, School of GeoSciences, The King's Buildings, West Mains Road, Edinburgh, EH9 3JW, UK
}

Correspondence to: Jens Zinke (jens.zinke@gmail.com)

Received: 29 February 2016 - Published in Biogeosciences Discuss.: 3 March 2016

Revised: 16 August 2016 - Accepted: 29 September 2016 - Published: 25 October 2016

\begin{abstract}
The western Indian Ocean has been warming rapidly over recent decades, causing a greater number of extreme climatic events. It is therefore of paramount importance to improve our understanding of links between Indian Ocean sea surface temperature (SST) variability, climate change and sustainability of tropical coral reef ecosystems. Here we present monthly resolved coral $\mathrm{Sr} / \mathrm{Ca}$ records from two different locations from Rodrigues Island $\left(63^{\circ} \mathrm{E}\right.$, $\left.19^{\circ} \mathrm{S}\right)$ in the south-central Indian Ocean trade wind belt. We reconstruct SST based on a linear relationship with the $\mathrm{Sr} / \mathrm{Ca}$ proxy with records starting from 1781 and 1945, respectively. We assess relationships between the observed long-term SST and climate fluctuations related to the El Niño-Southern Oscillation (ENSO), the Subtropical Indian Ocean Dipole Mode (SIOD) and the Pacific Decadal Oscillation (PDO) between 1945 and 2006, respectively. The reproducibility of the $\mathrm{Sr} / \mathrm{Ca}$ records is assessed as are the potential impacts of diagenesis and corallite orientation on $\mathrm{Sr} / \mathrm{Ca}-\mathrm{SST}$ reconstructions. We calibrate individual robust $\mathrm{Sr} / \mathrm{Ca}$ records with in situ SST and various gridded SST products. The results show that the SST record from Cabri provides the first Indian Ocean coral proxy time series that
\end{abstract}

records the SST signature of the PDO in the south-central Indian Ocean since 1945. We suggest that additional records from Rodrigues Island can provide excellent records of SST variations in the southern Indian Ocean trade wind belt to unravel teleconnections with the SIOD/ENSO/PDO on longer timescales.

\section{Introduction}

The Indian Ocean has been warming steadily over the past century, with the western portion of the basin having experienced an increase in SST of up to $1.2^{\circ} \mathrm{C}$ over the past 60 years (Koll Roxy et al., 2014). The Indian Ocean has also taken up a large amount of heat in its interior between 1999 and 2016 when global SST increased at a smaller rate compared to previous decades (Lee et al., 2015). The strong Indian Ocean warming over the past century is thought to have contributed to a decreasing land-sea thermal contrast with the Indian subcontinent, affecting monsoon rainfall and potentially playing a major role in the decrease in eastern African rainfall between March and May in recent decades 
(Funk et al., 2008; Koll Roxy et al., 2015). The western Indian Ocean warming has also been shown to closely follow anthropogenic radiative forcing over the past century (Funk et al., 2008; Alory and Meyer, 2009; Koll Roxy et al., 2014). Furthermore, the western Indian Ocean warmed significantly during past El Niño events, with the 1997/98 event causing widespread coral bleaching and mortality (Sheppard, 2003). Synchronously, intrinsic climate modes to the Indian Ocean, like the Subtropical Indian Ocean Dipole Mode during austral summer (SIOD; Fig. 1a; Behera and Yamagata, 2001; Reason, 2001), can interfere with the Indian Oceanwide teleconnections in SST and rainfall caused by the El Niño-Southern Oscillation (ENSO) or behave independently (Hoell et al., 2016). Mounting evidence indicates that the Pacific Decadal Oscillation (PDO) or Pacific Decadal Variability (PDV) has teleconnections extending to the western Indian Ocean (Fig. 1b; Cole et al., 2000; Crüger et al., 2009). The positive PDO phase corresponds to warm western Indian Ocean SST anomalies (Fig. 1b; Deser et al., 2004), thought to exceed SST anomalies associated with ENSO (Krishnan and Sugi, 2003), particularly in the southwestern Indian Ocean (Meehl and $\mathrm{Hu}, 2006$ ). It is therefore of paramount importance to improve our understanding of links between Indian Ocean SST variability, global climate change and sustainability of tropical coral reef ecosystems. However, long-term observational records of Indian Ocean SST are sparse and are thought to be only reliable after the 1960s (Tokinaga et al., 2012).

Paleoclimate reconstructions of SST from massive corals have provided invaluable records for past SST trends and interannual to decadal variability in the western Indian Ocean (Charles et al., 1997; Cole et al., 2000; Cobb et al., 2001; Pfeiffer et al., 2004, 2009; Pfeiffer and Dullo, 2006; Nakamura et al., 2009; Crüger et al., 2009; Grove et al., 2013a, b; Zinke et al., 2008, 2009, 2014). Massive corals, such as Porites spp., can grow for centuries at a rate of 0.5 and $2 \mathrm{~cm} \mathrm{yr}^{-1}$. Therefore, down-core geochemical sampling of massive corals can yield reconstructed SST time series at approximately monthly resolution. As the coral precipitates its skeleton, trace elements and stable isotopes are incorporated in proportion to ambient SSTs (Felis and Pätzold, 2003). Both the $\mathrm{Sr} / \mathrm{Ca}$ ratio and $\delta^{18} \mathrm{O}$ composition of the coral aragonite have been shown to be reliable paleothermometers, with a negative relationship with SST (Alibert and McCulloch, 1997; Pfeiffer and Dullo, 2006; DeLong et al., 2012). A compilation of $\mathrm{Sr} / \mathrm{Ca}-\mathrm{SST}$ calibrations for Porites spp. revealed a mean $\mathrm{Sr} / \mathrm{Ca}$ relationship, with SST of $-0.061 \mathrm{mmol} \mathrm{mol}^{-1}$ per $1^{\circ} \mathrm{C} \mathrm{SST} \mathrm{increase} \mathrm{(Corrège,}$ 2006). Since $\mathrm{Sr}$ has a long oceanic residence time, skeletal $\mathrm{Sr} / \mathrm{Ca}$ is assumed to mainly reflect SST variability. The quality and accuracy of coral paleothermometers strongly depends on optimal sampling of the major growth axes (De Long et al., 2012). Furthermore, diagenetic alteration of coral aragonite can lead to errors in SST reconstructions, and it is important that this effect is identified and excluded based on petrographic analysis (McGregor and Gagan, 2003; Hendy et al., 2007; McGregor and Abram, 2008; Sayani et al., 2011; Smodej et al., 2015).

Currently, none of the coral proxy records from the western Indian Ocean cover the south-central Indian Ocean basin in the heart of the trade wind system and the Subtropical Indian Ocean Dipole Mode (Fig. 1c). Furthermore, all proxy records of interest for the trade wind belt are based on oxygen isotopes with the exception of two $\mathrm{Sr} / \mathrm{Ca}$ ratio records covering 1963 to 2008 from St Marie Island off the east of Madagascar (Grove et al., 2013a). The latter provided mixed results with discrepancies in terms of the long-term SST trend estimates due to the confounding effects of coral calcification in at least one core (Grove et al., 2013a). A coral oxygen isotope record from Réunion Island $\left(21^{\circ} \mathrm{S}, 55^{\circ} \mathrm{E}\right.$; Mascarene Islands) located approximately $230 \mathrm{~km}$ to the southwest of Mauritius spans the period 1832 to 1994 and is the longest for the subtropical region off the east of Madagascar (Pfeiffer et al., 2004). Pfeiffer et al. (2004) showed evidence that the La Réunion coral dominantly recorded past variation in salinity associated with transport changes of the South Equatorial Current (SEC). The proxy time series records decadal anomalies that were opposite to those of SST. Crüger et al. (2009) reported close linkages of the salinity, sea-level pressure (SLP) and SST signal associated with the Pacific Decadal Oscillation (Mantua et al., 1997) in coral records from Réunion and Ifaty (in the southwest of Madagascar), respectively. Two coral oxygen isotope records from the Seychelles located in the tropical western Indian Ocean $\left(5^{\circ} \mathrm{S}\right.$, $54^{\circ} \mathrm{E}$ ) were interpreted as an excellent record of past southwest monsoon SST changes and showed significant correlations with air temperatures over India between 1847 to 1994 (Charles et al., 1997; Pfeiffer and Dullo, 2006). Both the Réunion and Seychelles records record strong correlations with the ENSO on interannual and decadal timescales (Pfeiffer and Dullo, 2006). Although the PDO also has a strong impact on the SST in the southwest Indian Ocean (Fig. 1c; Krishnan and Sugi, 2003; Deser et al., 2004), the SST signature of the PDO has not been reported in coral records from this region to date.

Here, we aim to reconstruct past SSTs from $\mathrm{Sr} / \mathrm{Ca}$ ratios in two coral cores obtained from Rodrigues Island $\left(19^{\circ} \mathrm{S}\right.$, $63^{\circ} \mathrm{E}$ ) located $690 \mathrm{~km}$ to the northeast of Mauritius within the trade wind belt of the south-central Indian Ocean. To obtain a robust SST record, we assess the reproducibility of the $\mathrm{Sr} / \mathrm{Ca}$ proxy, and provide a rigorous assessment of the potential impacts of diagenesis and corallite orientation on $\mathrm{Sr} / \mathrm{Ca}-\mathrm{SST}$ reconstructions. We calibrate individual $\mathrm{Sr} / \mathrm{Ca}$ records with in situ SST and various gridded SST products, and verify the suitability of SST products for climate studies in the south-central Indian Ocean. Furthermore, we assess relationships between the observed long-term SST and climate fluctuations related to the ENSO (Kaplan et al., 1998), the SIOD (Behera and Yamagata, 2001) and the PDO (Mantua et al., 1997) between 1945 and 2006. 

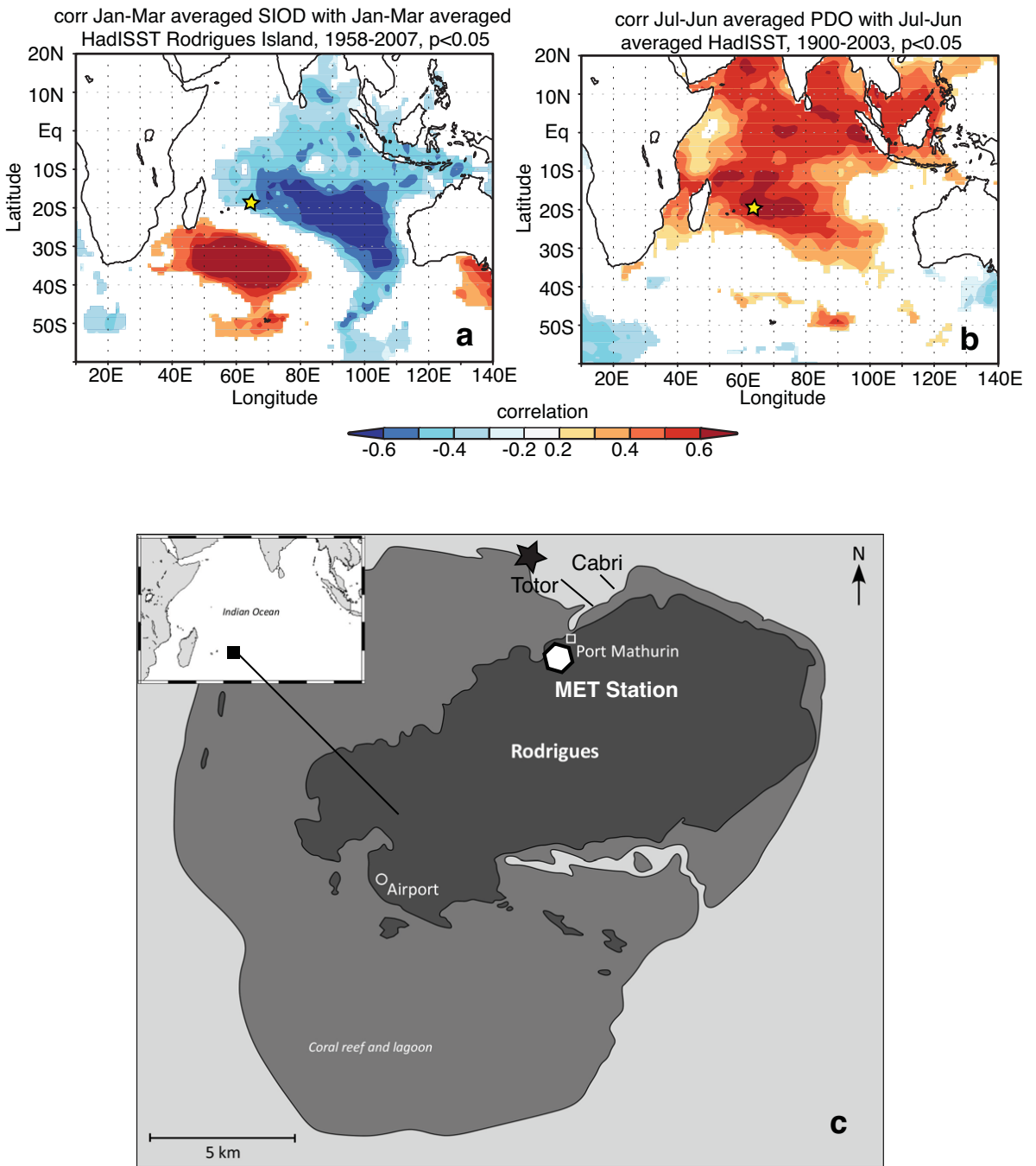

Figure 1. (a) Spatial correlation between January and March averaged SIOD index (Behera and Yamagata, 2001) with HadISST (Rayner et al., 2003) for Rodrigues Island. (b) Spatial correlation between July and June mean annual averaged PDO index (Mantua et al., 1997) with HadISST (Rayner et al., 2003). All correlations with detrended data. Only correlations with $p<0.05$ are coloured. Computed at KNMI Climate Explorer (van Oldenborgh and Burgers, 2005). The yellow star in (a) and (b) marks the location of Rodrigues Island. (c) Map of Rodrigues Island with the position of the two coral cores at Totor and Cabri indicated. The star shows the position of the CTD that collects SST and salinity data. The polygon indicates the location of the meteorological station, which records air temperature, sunshine hours, wind speed and rainfall.

\section{Regional setting and climate}

Rodrigues $\left(63^{\circ} \mathrm{E}, 19^{\circ} \mathrm{S}\right)$ is a small volcanic island in the southern Indian Ocean, about $619 \mathrm{~km}$ east of Mauritius (Fig. 1c). It is part of the eastern edge of the Mascarene Plateau that comprises Lower Tertiary basalts (Mart, 1988) formed by a seaward flow of lava, which has been eroded by hydrodynamic forces and biological and chemical processes (Turner and Klaus, 2005). Rodrigues has a surface area of about $119 \mathrm{~km}^{2}$, with a maximum altitude of $396 \mathrm{~m}$ a.s.l., and is surrounded by a nearly continuous fringing reef approximately $90 \mathrm{~km}$ in length (Turner and Klaus, 2005; Lynch et al., 2002). The reef encloses a shallow lagoon, which, at
$240 \mathrm{~km}^{2}$, is twice the area of the island itself. The maximum tidal range is approximately $1.5 \mathrm{~m}$, and since the average water depth in the lagoon is less than $2 \mathrm{~m}$, some areas are exposed at low spring tides. The water depth immediately beyond the reef slopes is usually within the range of 10 to $30 \mathrm{~m}$. The island has three major channels, one dredged for the main harbour at Port Mathurin in the north, and natural channels in the south near Port Sud Est and in the east at St Francois. Several small passes are also found around the reef (Turner and Klaus, 2005).

The water surrounding Rodrigues is supplied by the South Equatorial Current (SEC) (New et al., 2005, 2007), a broad east to west current between 10 and $20^{\circ} \mathrm{S}$ in the Indian Ocean 
Table 1. Coral cores with their GPS co-ordinates and colony depths at low tide, with mean rates of extension, density and calcification over the complete length of the individual records (1907 to 2006 for Cabri; 1781 to 2005 for Totor).

\begin{tabular}{|c|c|c|c|c|c|c|}
\hline $\begin{array}{l}\text { Core } \\
\text { name }\end{array}$ & $\begin{array}{l}\text { GPS } \\
\text { position }\end{array}$ & Species & $\begin{array}{r}\text { Water } \\
\text { depth } \\
(\mathrm{m})\end{array}$ & $\begin{array}{l}\text { Mean } \\
\text { growth } \\
\text { rate } \mathrm{mm} \mathrm{yr}^{-1}\end{array}$ & $\begin{array}{l}\text { Mean } \\
\text { density } \\
\mathrm{g} \mathrm{cm}^{-3}\end{array}$ & $\begin{array}{l}\text { Mean } \\
\text { Calcification } \\
\text { rate } \mathrm{g} \mathrm{cm}^{-2} \mathrm{yr}^{-1}\end{array}$ \\
\hline Totor & $\begin{array}{l}\mathrm{S} 19^{\circ} 40.237 \\
\mathrm{E} 63^{\circ} 25.754\end{array}$ & $\begin{array}{l}\text { Porites } \\
s p .\end{array}$ & $\begin{array}{l}4.0 \\
4.0\end{array}$ & $\begin{array}{l}9.2 \\
( \pm 0.19)\end{array}$ & $\begin{array}{l}1.128 \\
( \pm 0.11)\end{array}$ & $\begin{array}{l}1.07 \\
( \pm 0.18)\end{array}$ \\
\hline Cabri & $\begin{array}{l}\mathrm{S} 19^{\circ} 40.030 \\
\mathrm{E} 63^{\circ} 26.065\end{array}$ & $\begin{array}{l}\text { Porites } \\
\text { lobata }\end{array}$ & $\begin{array}{l}3.0 \\
3.0\end{array}$ & $\begin{array}{l}11.8 \\
( \pm 0.25)\end{array}$ & $\begin{array}{l}1.36 \\
( \pm 0.12)\end{array}$ & $\begin{array}{l}1.60 \\
( \pm 0.16)\end{array}$ \\
\hline
\end{tabular}

driven by the southeast trade winds (Schott and McCreary, 2001). The southern part of the SEC water flows in several directions past Rodrigues, occurring mostly in southwest and southeast directions, and westward of Mauritius (New et al., 2005, 2007).

Rodrigues has a relatively dry climate, and annual mean evaporation exceeds precipitation. Yearly precipitation is $\sim 1000 \mathrm{~mm}$, mostly from January to April, related to the position of the intertropical convergent zone (ITCZ). Between November and March, the Southern Indian Ocean is affected by tropical cyclones, as a result of warm SSTs and a strong convergence between northeast and southeast trades. Rodrigues experiences two to sixteen cyclones per year, of which 2.5 are extreme (category 3 and higher) with winds of $280 \mathrm{~km} \mathrm{~h}^{-1}$ and storm surges that reach $100 \mathrm{~m}$ inland and $2 \mathrm{~m}$ a.s.l. They usually last 5 to 10 days (Turner and Klaus, 2005).

SST was monitored hourly in situ by a conductivity, temperature and depth (CTD) device $150 \mathrm{~m}$ offshore the northern fringing reefs at Totor between 2002 and 2006 (Hardman et al., 2004, 2008). Maximum SSTs are recorded between December and March $\left(28.6 \pm 0.5^{\circ} \mathrm{C}\right)$ and minimum SST between July and September $\left(22.4 \pm 0.27^{\circ} \mathrm{C}\right)$. Annual mean SST is $25.49 \pm 0.24^{\circ} \mathrm{C}$ with a seasonal amplitude of $6.22 \pm 0.68^{\circ} \mathrm{C}$.

Air temperatures have been recorded by the WMO weather station 61988 (name: Rodrigues, Mauritius), located on the northern coast of Rodrigues, since 1951 and are available at http://climexp.knmi.nl/. The most recent years between 1997 and 2007 have been provided by the Rodrigues Meteorological Office. The warmest months are December to March $\left(31.2 \pm 0.3^{\circ}\right)$; the coldest months are July to September $\left(24.2 \pm 0.3^{\circ}\right)$. Yearly average air temperature is $27.49 \pm 0.31^{\circ} \mathrm{C}$ with a yearly amplitude of about $7 \pm 0.79^{\circ} \mathrm{C}$.

\section{Materials and Methods}

Two coral cores were drilled from massive, dome-shaped Porites sp. and Porites lobata at the northern reef sites Totor and Cabri, respectively (Fig. 1a; Table 1). The size of the coral colony at Totor is $\sim 2.5 \mathrm{~m}$ and that of Cabri is $\sim 4 \mathrm{~m}$ in height. Both colonies were healthy and showed no signs of disease or dead surfaces at the time of drilling. The $220 \mathrm{~cm}$ long Totor core was obtained in August 2005 from a colony on the forereef slope of the northern fringing reef facing the open ocean with the top of the colony at $4 \mathrm{~m}$ water depth. The $180 \mathrm{~cm}$ long Cabri core was obtained in March 2007 from a colony growing in $3 \mathrm{~m}$ water depth about $1 \mathrm{~km}$ to the northeast of Totor from the outer fringing reef at Passe Cabri. The site Cabri is more exposed to trade winds as compared to Totor that is more sheltered (Hardman et al., 2004, 2008).

A commercially available pneumatic drill driven by scuba tanks was used to extract cores along the central growth axis, with a diameter measuring $4 \mathrm{~cm}$. Cores were sectioned into $7 \mathrm{~mm}$ thick slabs, rinsed several times with demineralized water, cleaned with compressed air to remove any surficial particles and dried for more than $24 \mathrm{~h}$ in a laminar flow hood. Annual density bands were visualized by X-radiographpositive prints, and the growth axis of the coral slab was defined as the line normal to these laminae (Figs. A1 and $\mathrm{A} 2$ in the Appendix). Coral density $\left(\mathrm{g} \mathrm{cm}^{-3}\right)$ was calculated by analysing digital $\mathrm{X}$-rays using the program CoralXDS and densitometry (Fig. S1; Helmle et al., 2011; Carricart-Ganivet and Barnes, 2007), calcification rate $\left(\mathrm{g} \mathrm{cm}^{-2} \mathrm{yr}^{-1}\right)$ by multiplying density with extension rate. The annual extension rates $\left(\mathrm{cm} \mathrm{yr}^{-1}\right)$ were calculated by measuring the distance $(\mathrm{cm})$ between density minima using the program CoralXDS (Fig. S1 in the Supplement). With a diamond coated drill mounted on top of a movable support frame, samples for geochemical analysis were taken every $1 \mathrm{~mm}$ parallel to the growth axis, equivalent to approximately monthly resolution.

A combination of X-ray images, X-ray diffraction (XRD), light and scanning electron microscopy (SEM) with Energy Dispersive X-Ray Spectrometry (EDS) was used to investigate possible diagenetic alteration in the Totor and Cabri core sections. All core sections from both Totor and Cabri were initially screened for diagenetic alterations using Xray images (Figs. A1 and A2 in the Appendix). Core sections that showed an annual density banding without anomalous high- or low-density patches were selected for further study and considered free from obvious diagenetic alteration. Representative samples were selected from both cores based on the X-ray images for SEM and thin-section and XRD 
analysis. Additional samples were selected along the geochemical sampling tracks targeting intervals with unusually high or low $\mathrm{Sr} / \mathrm{Ca}$ ratios. The powder-XRD diffractometer at Rheinisch-Westfaelische Technische Hochschule (RWTH) Aachen University was calibrated to detect and quantify very low calcite contents above $\sim 0.2 \%$ following the method of Smodej et al. (2015). In addition, the 2-D-XRD system Bruker D8 ADVANCE GADDS was used for XRD pointmeasurements directly on the coral slab with a spatial resolution of $\sim 4 \mathrm{~mm}$ and a calcite detection limit of $\sim 0.2 \%$ (Smodej et al., 2015). A 2-D detector allows the simultaneous data collection over a large $2 \theta$ range, which reduces the counting time to $10 \mathrm{~min}$ for each sampling spot. The coral is mounted on a motorized XYZ stage, and the position of each sample spot is controlled by an automated laser-video alignment system. Multiple sample points can be predefined and measured automatically. This method was used to test for the presence of secondary calcite along the sampling traces of both corals.

$\mathrm{Sr} / \mathrm{Ca}$ ratios were measured at the University of Kiel with a simultaneous inductively coupled plasma optical emission spectrometer (ICP-OES, Spectro Ciros CCD SOP; Zinke et al., 2014). Approximately $0.5 \mathrm{mg}$ of coral powder was dissolved in $1.00 \mathrm{~mL} 0.2 \mathrm{M} \mathrm{HNO}_{3}$. Prior to analysis, the solution was diluted with $0.2 \mathrm{M} \mathrm{HNO}_{3}$ to a final concentration of $\sim 8 \mathrm{ppm} \mathrm{Ca}$. An analogue in-house coral powder standard (Mayotte) was analysed after every six samples. The international reference material JCp-1 (coral powder) was analysed with every sample batch. All calibration solutions are matrix-matched to $8 \mathrm{ppm} \mathrm{Ca}$. Strontium and $\mathrm{Ca}$ are measured at their 407 and $317 \mathrm{~nm}$ emission lines. Our intensity ratio calibration strategy combines the techniques described by de Villiers et al. (2002) and Schrag (1999). Analytical precision of $\mathrm{Sr} / \mathrm{Ca}$ determinations as estimated from replicate measurements of unknown samples is $0.15 \%$ or $0.01 \mathrm{mmol} \mathrm{mol}^{-1}(1 \sigma)$.

The coral core chronologies were developed based on the seasonal cycle of $\mathrm{Sr} / \mathrm{Ca}$. We assigned the coldest month (either August or September) to the highest measured $\mathrm{Sr} / \mathrm{Ca}$ ratio ( $\mathrm{Sr} / \mathrm{Ca}$ maxima) in any given year, according to both in situ SST and grid-SST (extended reconstructed SST; Smith et al., 2008). We then interpolated linearly between these anchor points to obtain age assignments for all other $\mathrm{Sr} / \mathrm{Ca}$ measurements. In a second step, the $\mathrm{Sr} / \mathrm{Ca}$ data were interpolated to 12 equidistant points per year to obtain monthly time series using AnalySeries 2.0 (Paillard et al., 1996). This approach creates a non-cumulative timescale error of 1-2 months in any given year, due to interannual differences in the exact timing of peak SST. The monthly interpolated $\mathrm{Sr} / \mathrm{Ca}$ time series were cross-checked with the chronologies from coral XDS to reveal the timing of highand low-density banding. High-density bands in both corals formed in summer (low $\mathrm{Sr} / \mathrm{Ca}$ ) of any given year.

We extracted coral proxy data for comparison to our Rodrigues time series from the NOAA paleoclimate data archive (https://www.ncdc.noaa.gov/data-access/ paleoclimatology-data/datasets/coral-sclerosponge). We used the time series for the Seychelles (Pfeiffer and Dullo, 2006), La Réunion (Pfeiffer et al., 2004) and St Marie Island (Grove et al., 2013).

\section{Historical SST data and climate indices}

Historical SST data collected primarily by ships of opportunity have been summarized in the comprehensive ocean atmosphere dataset (ICOADS) to produce monthly averages on a $2^{\circ} \times 2^{\circ}$ grid basis (Woodruff et al., 2011). In the grid that includes Rodrigues Island the data are extremely sparse (Fig. A3). Since the uncertainty in SST bias adjustments due to measurement errors is much larger for the Southern Hemisphere than the Northern Hemisphere (Jones, 2016) data, we therefore extracted various SST and marine air temperature datasets for our region for comparison with our coral proxy data. We extracted SST from extended reconstructed SST (ERSST3b, Smith et al., 2008; ERSST4, Huang et al., 2015), also based on ICOADS data, which uses sophisticated statistical methods to reconstruct SST from sparse data. From ERSST, we extracted data in the $2^{\circ} \times 2^{\circ}$ grid centred at $61-$ $63^{\circ} \mathrm{E}, 19-21^{\circ} \mathrm{S}$ (Table A1 in the Appendix). Furthermore, we used Met Office Hadley Centre's sea ice and sea surface temperature (HadISST) data for the grid $62-63^{\circ} \mathrm{E}, 19$ $20^{\circ} \mathrm{S}$ (Rayner et al., 2003; Kennedy et al., 2011). HadISST temperatures were reconstructed using a two-stage reducedspace optimal interpolation procedure, followed by superposition of quality-improved gridded observations onto the reconstructions to restore local detail. Since January 1982, SST time series for HadISST have used the optimal interpolation SST (OISST; $1^{\circ} \times 1^{\circ}$ ), version 2 (Reynolds et al., 2002), which includes continuous time series of satellite-based SST measurements. We also extracted Advanced Very High Resolution Radiometer (AVHRR) SST at $0.25^{\circ} \times 0.25^{\circ}$ resolution (Reynolds et al., 2007; Table A1) from 1985 to 2006. SST data from the $5^{\circ} \times 5^{\circ} \mathrm{HadSST} 3$, the most sophisticated bias-corrected SST data to date, were downloaded for the region $60-65^{\circ} \mathrm{E}, 15-20^{\circ} \mathrm{S}$ (Kennedy et al., 2011) but contain data gaps throughout the record due to strict quality control. SST is reported as anomalies relative to the 1961 to 1990 mean climatology. In addition, we extracted $5^{\circ} \times 5^{\circ}$ nightime marine air temperature data from HadMAT 1 and HadNMAT2 datasets (Kent et al., 2013). HadNMAT2 also contains data gaps throughout the record due to strict quality control. Night-time marine surface air temperature is highly correlated with SST but free of the biases introduced by changes in SST measurement techniques (Tokinaga et al., 2012).

All climate indices used for comparison with instrumental and coral proxy data were extracted from the Royal Netherlands Meteorological Institute (KNMI) online tool Climate Explorer (Trouet and van Oldenborgh, 2005). We extracted the time series for the Subtropical Indian Ocean Dipole Mode (SIOD; Behera and Yamagata, 2001), the El Niño-Southern 
Oscillation (ENSO; Kaplan et al., 1998) and the Pacific Decadal Oscillation (PDO; Mantua et al., 1997).

Statistical analysis includes linear correlation for linearly detrended data only with climate indices and instrumental data with $95 \%$ confidence limits indicated for the correlation coefficients using a Monte Carlo approach (Trouet and van Oldenborgh, 2005; see the Supplement). Spatial correlations for linearly detrended data were only computed at KNMI Climate Explorer (van Oldenborgh and Burgers, 2005), only taking into account correlations with $p<0.05$.

\section{Results}

\subsection{Coral $\mathrm{Sr} / \mathrm{Ca}$ seasonality, variability and trends}

The average growth rate of the corals Totor (224 years) and Cabri (130 years) were $9.82 \pm 0.19 \mathrm{~mm} \mathrm{yr}^{-1}$ and $11.79 \pm 0.25 \mathrm{~mm} \mathrm{yr}^{-1}$, respectively (Table 1; Fig. S1 in the Supplement). The Cabri core shows a growth disturbance at 1907 that led to partial colony mortality (see the Supplement). This lower core section is overprinted by diagenesis and it is therefore not suitable for climate studies or to determine density and calcification rates.

For the period of overlap (1945 to 2005) there is an offset in mean $\mathrm{Sr} / \mathrm{Ca}$ of $0.0242 \mathrm{mmol} \mathrm{mol}^{-1}$ between the two colonies. Both cores show a distinct seasonality in $\mathrm{Sr} / \mathrm{Ca}$ throughout their record length. The seasonality in the Totor core $\left(0.283 \pm 0.049 \mathrm{mmol} \mathrm{mol}^{-1}\right)$ is on average slightly higher compared to the Cabri core $\left(0.238 \pm 0.055 \mathrm{mmol} \mathrm{mol}^{-1}\right)$; yet the difference is not statistically significant (both overlap within $1 \sigma$ ). To eliminate the offset between $\mathrm{Sr} / \mathrm{Ca}$ time series we calculated $\mathrm{Sr} / \mathrm{Ca}$ anomalies by subtracting their mean relative to the 1961 to 1990 reference period (Fig. 2a).

Between 1945 and 2006 both cores record higher Sr / Ca anomalies relative to 1961-1990 (a period of cooling) that started in the mid-1950s and lasted until the early 1970s. Both cores show a pronounced trend to more negative $\mathrm{Sr} / \mathrm{Ca}$ values (warming) starting in the 1970s (Fig. 2a). After 1984 $\mathrm{Sr} / \mathrm{Ca}$ in the Cabri core further decreases (warms) while $\mathrm{Sr} / \mathrm{Ca}$ in the Totor core records no trend. This highlights that the long-term trend estimates after 1984 need to be viewed with caution.

The $\mathrm{Sr} / \mathrm{Ca}$ time series in the Totor core extends to 1781 (Fig. 2a). Marked negative $\mathrm{Sr} / \mathrm{Ca}$ anomalies (warmer) are observed during the first half of the 20th century centred at 1918/19, 1936-1941 and in the period 1948-1951 that exceed anomalies in the 1961 to 1990 reference period. $\mathrm{Sr} / \mathrm{Ca}$ anomalies between 1850 and 1890 are higher (cooler) while decadal periods with lower (warmer) $\mathrm{Sr} / \mathrm{Ca}$ are observed between 1781 and 1850 relative to 1961 to 1990 .
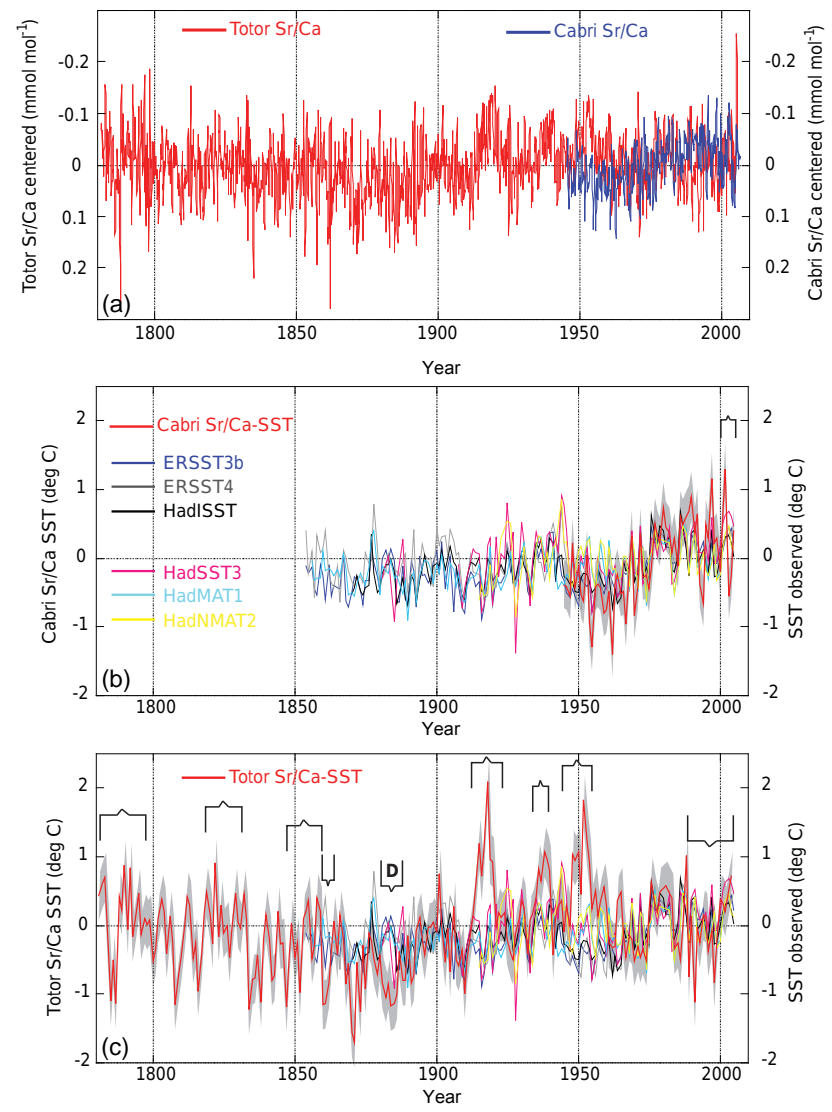

Figure 2. (a) Time series of monthly (thin solid lines) $\mathrm{Sr} / \mathrm{Ca}$ anomalies (right $Y$ axis inverted) relative to the 1961 to 1990 climatological mean for coral cores Cabri (blue), Totor (red) for the period 1781 to 2006. Annual mean time series of individual coralderived SST (red line) (b) Cabri and (c) Totor compared to SST reconstructions: ERSSTv3b, ERSSTv4, HadISST, HadSST3, HadMAT1 and HadNMAT2. See legend in (b) and (c) for colour code. For all time series we computed anomalies relative to 1961 to 1990. The uncertainty of mean annual coral $\mathrm{Sr} / \mathrm{Ca}-\mathrm{SST}$ anomalies is indicated by the grey envelope. Potential warm bias in coral SST is indicated by brackets, pointing up for warm and down for potential cool biases, respectively. Bracket with inset D marks core interval with diagenesis (cool anomaly).

\subsection{Diagenetic tests for alterations of $\mathrm{Sr} / \mathrm{Ca}$ profiles}

Representative samples for diagenetic screening with XRD, SEM and light microscopy were identified on the coral slabs using the X-radiographs (Figs. A1 and A2). Additionally, intervals with presumably anomalous proxy values (warm or cold anomalies) were analysed with the same methods. Ten thin sections, six SEM samples, ten powder-XRD and thirteen spot-2-D-XRD samples were analysed from coral core Totor (Fig. 3). For coral core Cabri, seven thin sections, one powder-XRD and six 2-D-XRD samples, were analysed. Neither powder nor spot-XRD analysis detected any calcite. Thin-section analysis indicates a growth break within core 

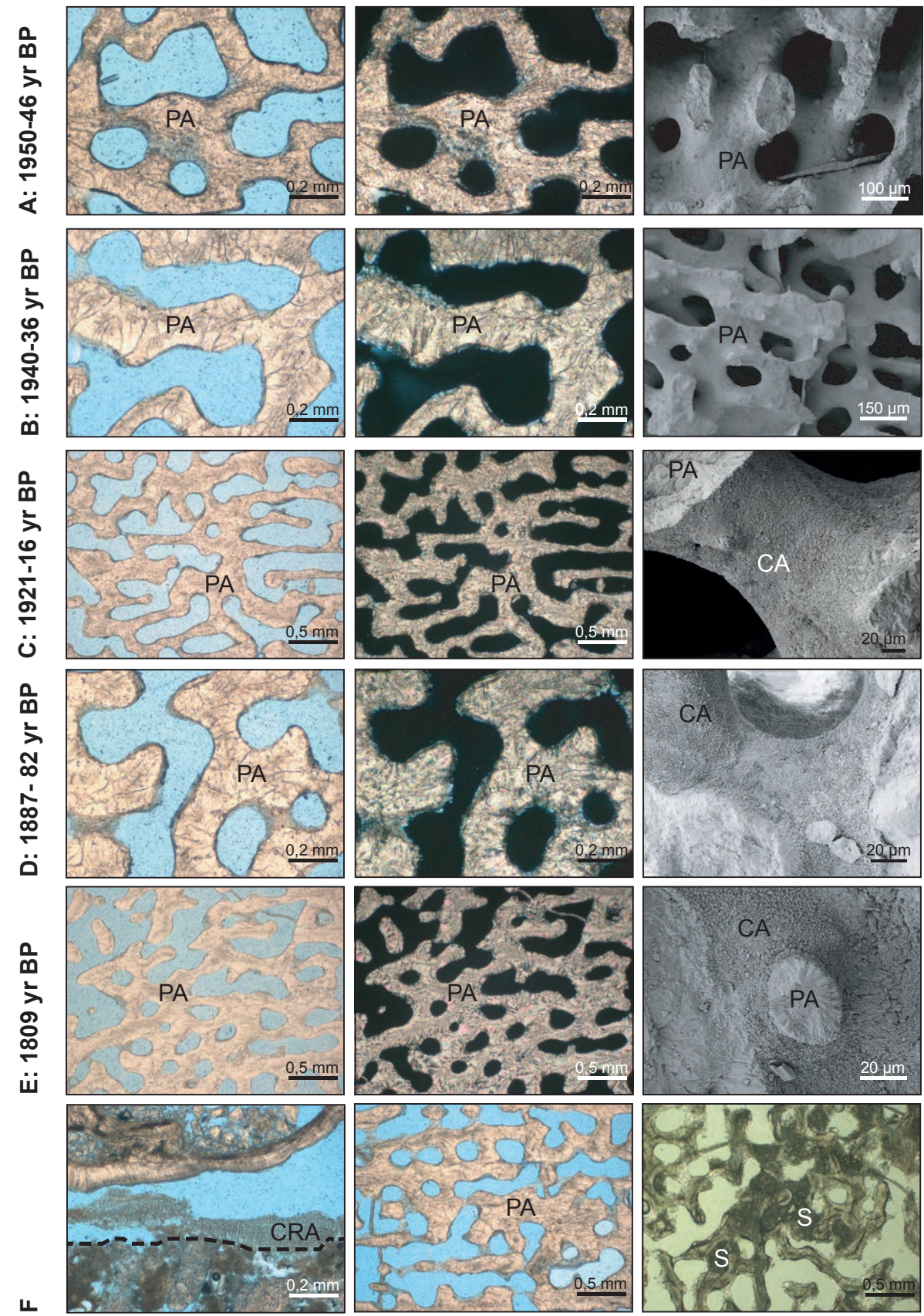

Figure 3. Thin-section and SEM images of primary coral aragonite (PA) and aragonite cement (AC) in cores Totor and Cabri. (a) and (b): excellent preservation of the primary coral aragonite in core section $4 \mathrm{~A}$ and $4 \mathrm{~B}$ in Totor. Trace amounts of aragonite cements occur as isolated patches in core sections 6 (c), 7 (d) and 11 (e) of Totor. (f) Left: a prominent growth break (stippled line) in core section 12 of Totor is encrusted by coralline red algae (CRA). (f) Middle: the section above the growth break shows well preserved primary coral aragonite. (f) Right: the pristine coral skeleton of core Cabri contains locally aragonitic sediment (S) partially filling growth-framework pores. (a-f): thin section photographs are shown in plane- (left) and cross-polarized light (middle). (a-e): scanning electron microscopy images (right).

section 12 of Totor that is also apparent in the radiograph (Fig. A1). Close to this break the coral is strongly affected by bioerosion and encrustation by red algae (Fig. 3f). The sampling transect for geochemical analysis, however, excluded this area, and therefore the reported data are not affected by diagenesis. Combined SEM, EDS and XRD analysis shows low amounts of patchy distributed isopachous $(\sim 2 \mu \mathrm{m}) \mathrm{fi}-$ brous aragonite cement in Totor core section 6 (1916-1921; Fig. 3c), 7 (1882-1887; Fig. 3d) and 11 ( 1809; Fig. 3e). 


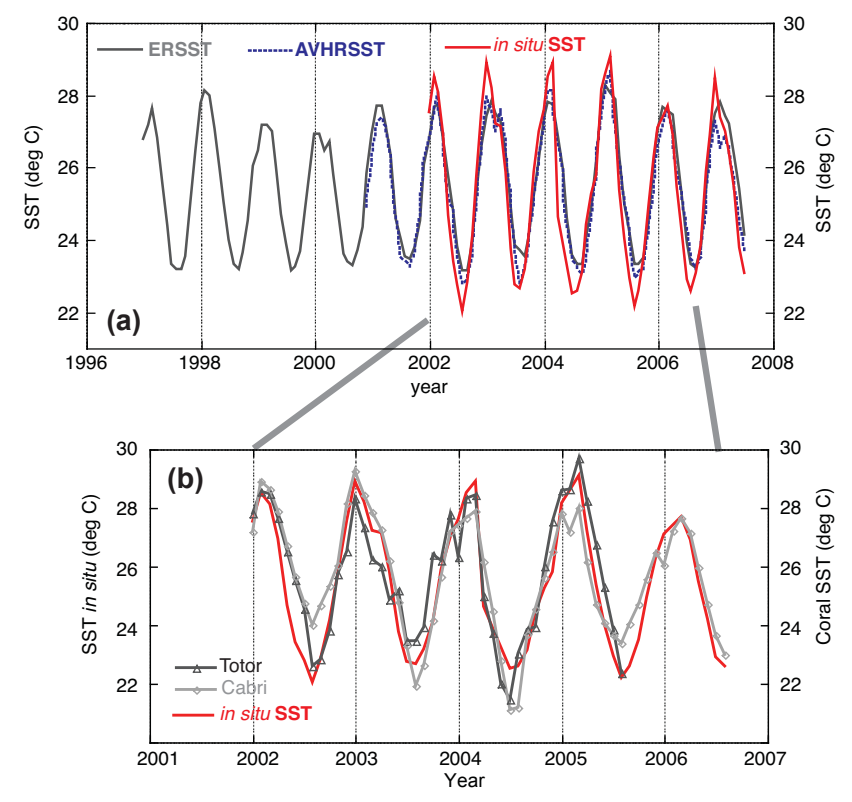

Figure 4. (a) Climatology at Rodrigues between 1997 and 2007. Monthly averaged SST in situ (red), ERSSTv.3b (grey; Smith et al., 2008) and AVHRR SST (blue stippled; Reynolds et al., 2007); (b) reconstructed absolute SST from coral Sr / Ca from cores Totor (dark grey with triangle) and Cabri (light grey with diamond) for 2002 to 2006 based on calibration with in situ SST from Rodrigues (red). The uncertainty for single month absolute SST for individual cores Cabri and Totor is 1.23 and $1.05^{\circ} \mathrm{C}(1 \sigma)$, respectively. The coral data agree with in situ SST within the $1 \sigma$ uncertainty.

Aragonite cement should lead to higher $\mathrm{Sr} / \mathrm{Ca}$ values and lower reconstructed temperatures (Hendy et al., 2007). An interesting outcome is that the observed diagenesis is not able to explain changes in the $\mathrm{Sr} / \mathrm{Ca}$ ratios except for the Totor core section 7 . Here the observed aragonite cement is associated with relatively high $\mathrm{Sr} / \mathrm{Ca}$ values, resulting in an apparent cold anomaly. No anomalously high $\mathrm{Sr} / \mathrm{Ca}$ ratios are associated with the patchy aragonite cements in Totor core sections 6 and 11. Instead core sections 6 and 11 are characterized by low $\mathrm{Sr} / \mathrm{Ca}$ ratios, resulting in apparent relatively warm reconstructed temperatures. All other samples from the core sections Totor 3, 4, 8, 9 and 10 are devoid of diagenetic alteration. In summary, a diagenetic influence on the proxy record and resulting SST reconstructions are only evident for Totor core section 7 (years 1882-1887). Core Cabri only showed localized (single month) positive $\mathrm{Sr} / \mathrm{Ca}$ anomalies (cool SST bias; Fig. 3f). Thin-section and XRD analysis did not establish any diagenetic alteration, but the coral locally contained aragonitic sediment partially filling pore spaces (Fig. 3f). This aragonitic sediment potentially could have caused the isolated $\mathrm{Sr} / \mathrm{Ca}$ peaks (high $\mathrm{Sr} / \mathrm{Ca}$ ) in the record. These individual data points were omitted from further analysis.

\subsection{Calibration of coral $\mathrm{Sr} / \mathrm{Ca}-\mathrm{SST}$ with in situ and gridded SST}

SST seasonality does not differ significantly between SST products for the 2002 to 2006 period for which we had in situ SST. Therefore, the coral Sr / Ca from both cores was calibrated with in situ SST, ERSSTv.3b and AVHRR SST for the period 2002 to 2006 using the minima and maxima in any given year, as well as monthly values with AVHRR SST for 1981 to 2006 (Fig. 4; Table A2). There is a relatively large variance in the $\mathrm{Sr} / \mathrm{Ca}-\mathrm{SST}$ relationships depending on the coral core and the SST record. The slopes of the ordinary least squares regressions vary between -0.0384 and $-0.0638 \mathrm{mmol} \mathrm{mol}^{-1}$ per $1{ }^{\circ} \mathrm{C}$ (Table A2). The lowest slopes are obtained with in situ SST and the highest with ERSSTv.3b (Table A2). The range of this variance is consistent with the results of Corrège (2006), who used a set of more than 30 coral $\mathrm{Sr} / \mathrm{Ca}$ records from various ocean basins and different coral genera. We reconstructed absolute SST for the period of overlap with in situ SST from 2002 to 2006 from both coral cores (Fig. 4). The Sr / Ca-SST in the Totor core shows the best fit with in situ SST in terms of the seasonal amplitude. The $\mathrm{Sr} / \mathrm{Ca}-\mathrm{SST}$ in the Cabri core overestimates the winter SST of 2002 and 2005, yet agrees well for 2003 and 2004 (Fig. 4). Taking into account the uncertainties (measurement error, regression error) in absolute SST from $\mathrm{Sr} / \mathrm{Ca}$ for Cabri and Totor of 1.23 and $1.05^{\circ} \mathrm{C}(1 \sigma)$, respectively, the coral data agree with in situ SST within the $1 \sigma$ uncertainty.

\subsection{Validation of Sr / Ca-SST anomalies with gridded SST products}

To eliminate errors associated with absolute SST reconstructions from coral $\mathrm{Sr} / \mathrm{Ca}$ we calculated relative changes in SST for the coral temperature records relative to the 1961 to 1990 mean based on the established empirical relationship of $-0.0607 \mathrm{mmol} \mathrm{mol}^{-1}$ per $1{ }^{\circ} \mathrm{C}$ derived from $>30$ published $\mathrm{Sr} / \mathrm{Ca}$ calibrations (Corrège, 2006; Nurhati et al., 2011). This slope is well within the range of our regressions based on a variety of SST datasets and consistent with the results of Corrège (2006) (Table A2). We consider the mean $\mathrm{Sr} / \mathrm{Ca}-\mathrm{SST}$ slope of Corrège (2006) to be much more reliable than our short in situ calibration. We use a conservative estimate of the uncertainty around relative SST changes based on the difference between lower $(-0.04)$ and upper slope $(-0.084)$ estimates from these regression equations, thus $\pm 0.02 \mathrm{mmol}$ per $1{ }^{\circ} \mathrm{C}$ or $\pm 0.33^{\circ} \mathrm{C}$ (following Gagan et al., 2012; Table A2).

We validated the coral-derived annual mean SST reconstruction against local air temperature (AT), ERSSTv3b, ERSST4, HadISST, HadSST3, HadMAT1 and HadNMAT2 for the period 1951 to 2006 (Fig. 5; see Tables S1-S16 for mean annual correlations). We stress that the number of SST observations in the ICOADS SST and marine AT database is 


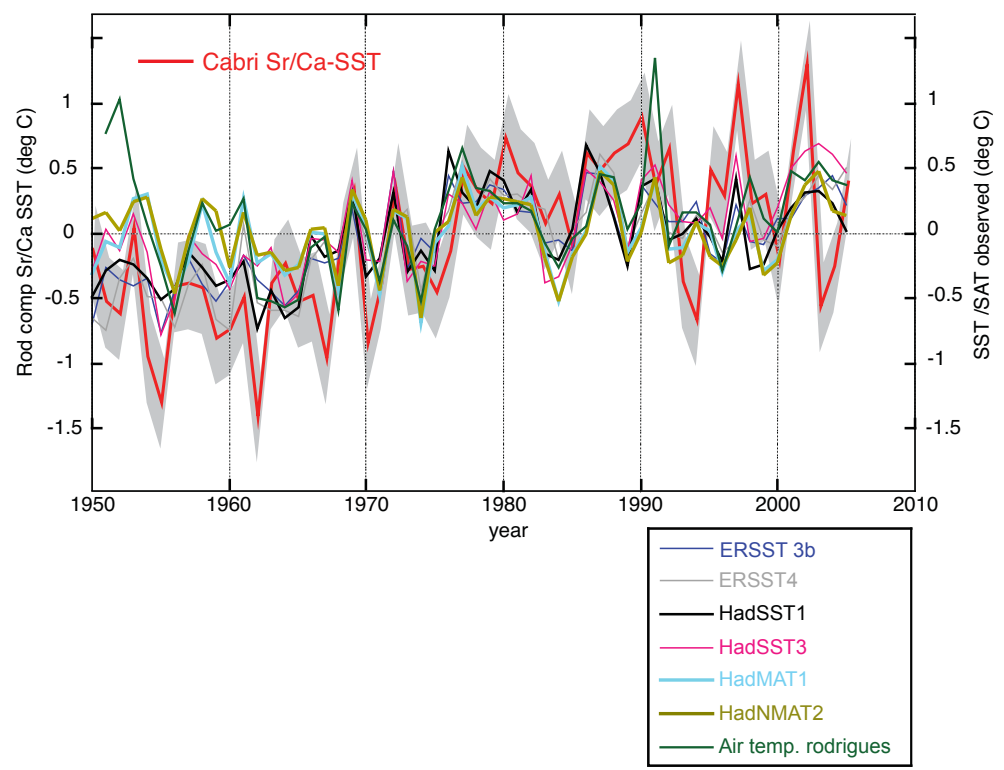

Figure 5. Time series of annual mean temperatures anomalies relative to the 1961-1990 mean for the coral Cabri SST reconstruction, Rodrigues weather station air temperature (AT), ERSSTv3b, ERSSTv4, HadISST, HadSST3, HadMAT1 and HadNMAT2 for the period 1950 to 2006. The uncertainty of mean annual coral Sr / Ca-SST anomalies is indicated by the grey envelope.

extremely sparse for our region (Fig. A3). The Cabri coral SST record records the highest correlations with HadISST and HadMAT1 in the grid box surrounding Rodrigues Island (Fig. A4), while the overall best fit is obtained with local Rodrigues AT. Core Totor has no significant correlations with both ERSST products and HadISST, yet shows significant correlations with HadSST3, HadMAT1 and HadNMAT2 (Tables S11, S15-S16). Discrepancies between AT and gridded SST products are observed between 1951 and 1955, with AT indicating significantly warmer temperatures. Cabri tracks grid-SST between 1951 and 1955, while Totor shows warm anomalies similar to AT. Taking into account the uncertainty of $\pm 0.33^{\circ} \mathrm{C}$ based on the regression error, however, Cabri SST agrees with gridded SST and AT within $1 \sigma$, while Totor shows less agreement.

For the period 1951 to 2005, we used AT, ERSSTv3b, ERSST4, HadISST, HadSST3, HadMAT1 and HadNMAT2 to validate trends in annual mean coral $\mathrm{Sr} / \mathrm{Ca}-\mathrm{SST}$ anomalies (Fig. 5). The uncertainty for the trend estimates in coral $\mathrm{Sr} / \mathrm{Ca}$ SST is calculated from the square root of the sum of squares of the regression error and the error in the slope of the $\mathrm{Sr} / \mathrm{Ca}-\mathrm{SST}$ relationship. The long-term trends in $\mathrm{Sr} / \mathrm{Ca}-$ derived SST anomalies for the period 1951 to 2005 for Cabri and Totor converted to SST, using the published Sr / Ca-SST relationship of $-0.0607 \mathrm{mmol} \mathrm{mol} \mathrm{per} 1{ }^{\circ} \mathrm{C}$, indicate a warming of $1.38 \pm 0.39^{\circ} \mathrm{C}$ and cooling of $-0.49 \pm 0.41^{\circ} \mathrm{C}$. Instrumental SST data indicate a warming trend of $0.61 \pm 0.13^{\circ} \mathrm{C}$ for HadISST, $0.72 \pm 0.11^{\circ} \mathrm{C}$ for ERSST3b $\left(0.86 \pm 0.12^{\circ} \mathrm{C}\right.$ for ERSST4) and $0.78 \pm 0.12^{\circ} \mathrm{C}$ for HadSST3. Air temperature at Rodrigues weather station recorded a warming trend of $0.46 \pm 0.17^{\circ} \mathrm{C}$. All trends are statistically significant at the
$98 \%$ level with the exception of the negative trend in $\mathrm{Sr} / \mathrm{Ca}$ SST anomalies in the Totor core which is not significant.

For the pre-1945 period we used ERSSTv3b, HadISST, HadSST3 HadMAT1 and HadNMAT2 to validate annual mean coral Sr / Ca-SST from core Totor (Fig. 2). We stress that the number of SST observations in the ICOADS SST and marine AT database is extremely sparse for our region (Fig. A3). In general, the Totor SST record is a valid reconstruction for the region surrounding Rodrigues Island for several decades with the possible exception of 1854-1860, 1916-1921, 1936-1941 and 1948-1951 (Fig. 2). The Totor coral SST time series displays significantly higher SST anomalies compared to all gridded SST reconstructions in the 1850s, between 1916-1921, 1936-1941 and 1948-1951, and lower SST anomalies for brief periods between 1850 and 1890. Interestingly, the Totor $\mathrm{Sr} / \mathrm{Ca}-\mathrm{SST}$ has significant correlations with HadSST3, HadMAT1 and HadNMAT2 observational time series only (Tables S11, S15-S16). The cool bias in coral-derived SST between 1882 and 1887 (core section 7) is related to diagenetic alterations, but none of the anomalously warm periods can be explained by diagenesis (see next section). We assessed the orientation of corallites relative to the coral slab surface to test for sampling artefacts that might have altered our $\mathrm{Sr} / \mathrm{Ca}$ data, which we summarized in Tables 2 and 3, illustrate in Fig. 2 and discuss in Sect. 6.1. Most anomalous warm periods show sub-optimal orientation of sampling path with corallites at an angle to the slab surface (see Sect. 6.1). 
a

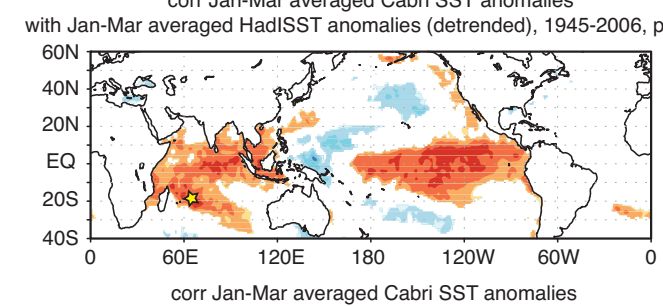

b

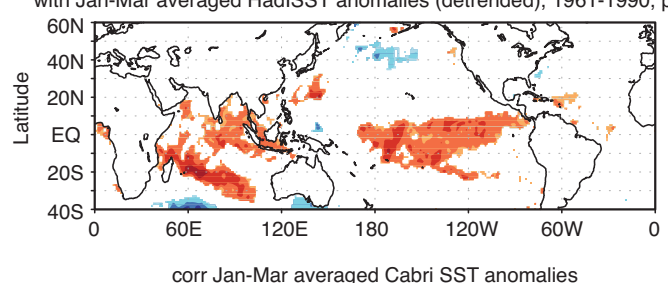

C with Jan-Mar averaged HadlSST anomalies (detrended), 1971-2006, $p<0.05$ TOS

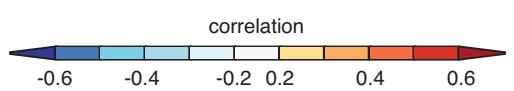

corr Jul-Jun averaged Cabri SST anomalies

d with Jul-Jun averaged HadISST anomalies (detrended), 1945-2006, $p<0.05$

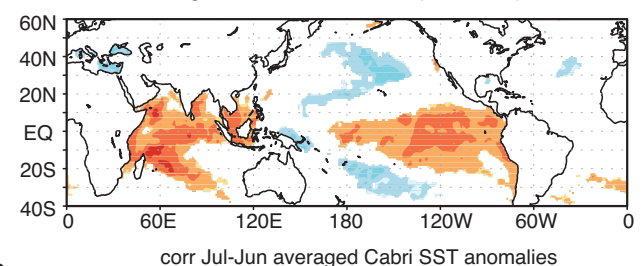

e

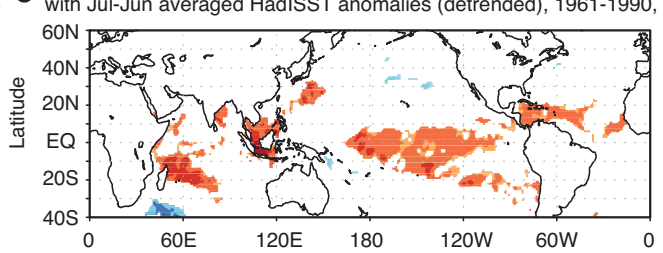

corr Jul-Jun averaged Cabri SST anomalies f with Jul-Jun averaged HadISST anomalies (detrended), 1971-2006, p<0.05

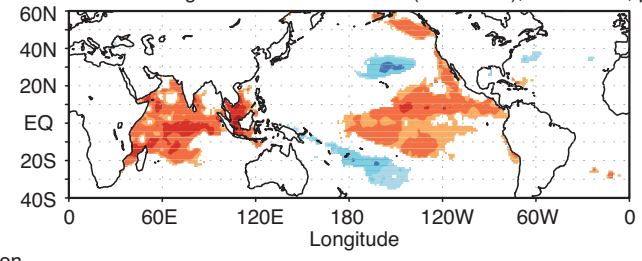

Figure 6. Spatial correlation of Cabri Sr / Ca-SST anomalies (relative to 1961-1990) with HadISST (Rayner et al., 2003). January to March austral summer in (a) between 1945-2006, (b) 1961-1990 and (c) 1971-2006. Annual mean correlations in (d) between 1945-2006, (e) 1961-1990 and (f) 1971-2006. Only correlations with $p<0.05$ are coloured. Computed at KNMI Climate Explorer (van Oldenborgh and Burgers, 2005). Yellow star in (a) marks location of Rodrigues Island.

\subsection{Large scale teleconnections between 1945 and 2006}

The large-scale teleconnections with SST are significant for the Cabri Sr/Ca-SST time series starting in 1945 (Figs. 6 and 7), while core Totor has statistically insignificant correlations in that period. This indicates that the Cabri time series is more reliable for the recent 60 years for monthly averages and annual means, and shows the strongest correlations across the Indo-Pacific (Figs. 6 and 7). Therefore, we assess the large-scale climate teleconnections only for the period between 1945 and 2006.

The detrended Cabri Sr/Ca-SST records shows significant positive correlations for austral summer and annual means with Indian Ocean-wide SST, a positive significant correlation with the central and eastern Pacific SST and negative significant correlations with North Pacific SST typical for the spatial ENSO and PDO pattern (Fig. 6; Tables S17S19). The detrended mean annual timescales (July-June) and austral summer (JFM) record for the Cabri SST indicate a positive significant correlation with southern Indian Ocean SST along a southeast to northwest band stretching along the trade wind belt (Fig. 6d-f). The correlation with the southern Indian Ocean trade wind belt remains stable over different record length and is most pronounced post 1971. The detrended Cabri record shows negative significant correla- tions $(r=-0.39 ; p<0.001 ; N=48)$ with the SIOD index for austral summer month. This agrees with similar sign and strength of correlations of HadISST for Rodrigues with the SIOD $(r=-0.43 ; p<0.001 ; N=48$; Fig. 1a; Tables S19$\mathrm{S} 21$ ). We find positive significant correlations with the eastern Pacific SST and negative correlations with the northern Pacific along $40^{\circ} \mathrm{N}$ and stretching between $160^{\circ} \mathrm{E}$ and $150^{\circ} \mathrm{W}$. The SST pattern mimics part of the typical spatial ENSO and PDO pattern across the Indo-Pacific (Mantua et al., 1997; McPhaden et al., 2006). Stratifying the correlations into negative and positive PDO phases between 19501975 and 1976-1999 reveals the PDO-like spatial SST pattern (Fig. 7).

Comparison with available coral proxy records from the wider trade wind belt region in the southwestern Indian Ocean (SWIO) between 12 to $21^{\circ} \mathrm{S}$ and 50 to $63^{\circ} \mathrm{E}$ reveals that the Cabri record agrees best with the $\mathrm{Sr} / \mathrm{Ca}-\mathrm{SST}$ from St Marie Island (core STM2 in Grove et al., 2013a; $r=0.25$; $N=50, p=0.08$; Fig. 8) on mean annual timescales, yet not with the La Réunion record (not shown). Cabri shows the highest significant correlation of the three coral records from SWIO with HadISST for the larger grid box between 12 to $21^{\circ} \mathrm{S}$ and 50 to $63^{\circ} \mathrm{E}(r=0.49, p=0.001, N=60)$, while both St Marie and La Réunion corals show no statistically significant correlations. 



Figure 7. Spatial correlations of Cabri coral SST (left) and HadISST grid for Rodrigues Island with global austral summer HadISST (right) for (a-c) 1950 to 1975 (February to May) negative PDO phase (Mantua et al., 1997) and (c-d) 1976 to 1999 (January to April) positive PDO phase. Only correlations with $p<0.05$ are coloured. Computed at KNMI Climate Explorer (van Oldenborgh and Burgers, 2005). Yellow star in (a) marks location of Rodrigues Island.

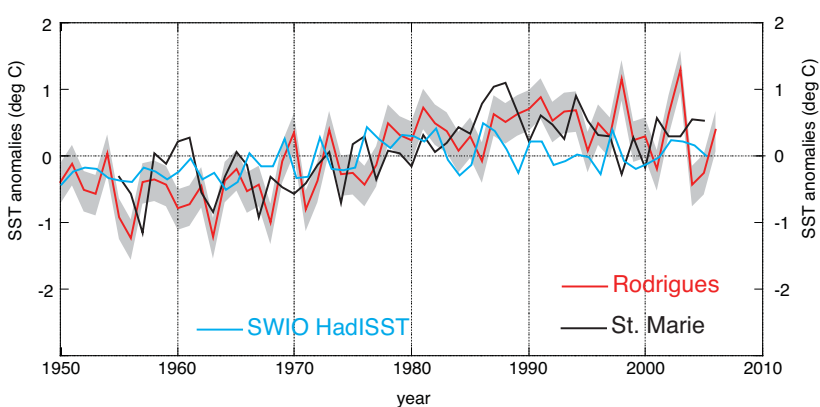

Figure 8. Comparison of southwestern Indian Ocean (SWIO) coral records from St Marie Island (black; Grove et al., 2013) with the Cabri record from Rodrigues (red). A SST time series for the grid box in the SWIO averaged between $12-20^{\circ} \mathrm{S}$ and $50-63^{\circ} \mathrm{E}$ is also illustrated (light blue). All times were annualized and converted to SST anomalies relative to 1961-1990. The uncertainty of mean annual Cabri Sr / Ca-SST anomalies is indicated by the grey envelope.

\section{Discussion}

\subsection{Diagenesis, coral growth pattern changes and potential biases in $\mathrm{Sr} / \mathrm{Ca}$ derived SST}

Generally diagenesis could be excluded as a major cause of discrepancies between coral SST and grid-SST. For core Totor, only for the period between 1882 and 1887 is diagenesis the cause of a cool bias on our coral SST recon- struction (Fig. 3d). Core Cabri showed only localized positive $\mathrm{Sr} / \mathrm{Ca}$ anomalies (cool SST bias) caused by aragonitic sediment trapped within growth framework pores (Fig. 3f). These specific samples were removed before interpolation. Having excluded diagenesis for almost all of the record, we assessed sampling biases due to changes in the orientation of growth axes and positioning of corallites to the slab surface (Table 2 and 3). De Long et al. (2012) showed clear evidence for warm or cool biases in coral $\mathrm{Sr} / \mathrm{Ca}-\mathrm{SST}$ reconstructions caused by suboptimal orientation of corallites in corals from New Caledonia. We have adopted a similar approach to test for sampling biases in our two cores (summarized in Tables 2 and 3). We found that core Totor contained areas where a sampling bias could explain anomalous Sr / Ca-derived SST (1781-1797, 1825-1835, 1854 1860, 1916-1921, 1936-1941 and 1948-1951, 1984-2001). We provide a detailed explanation of the potential biases in core Totor and its co-variability with a tropical western Indian Ocean coral SST reconstruction from the Seychelles pre 1900 (Pfeiffer and Dullo, 2006; Fig. S2) in the Supplement that is of particular importance for coral paleoclimatologists.

De Long et al. (2012) showed that warm biases were often caused by corallites orientated at an angle to the slab surface and where growth orientation had changed. Sampling of these suboptimal intervals will have seasonal cycles with more summer $\mathrm{Sr} / \mathrm{Ca}$ values than winter values, causing an apparent warm bias. Such a relationship could not be identified for core Totor, for instance for the largest single warm 
Table 2. Summary of sampling issues detected in core Totor.

\begin{tabular}{|c|c|c|c|c|}
\hline Section & Year & Orientation & Bias & Notes \\
\hline 1 & $2005-1987$ & Sub-optimal & Cool & Corallites parallel to surface, yet straight angle; probably like a valley \\
\hline 2 & 1987-1982 & Sub-optimal & Cool & Corallites parallel to surface, yet straight angle; probably like a valley \\
\hline $2^{\mathrm{a}}$ & 1981-1977 & Sub-optimal & None & Corallites at an angle to the surface; no bias \\
\hline $3^{\mathrm{a}}$ & $1978-1975$ & Sub-optimal & None & Corallites at an angle to the surface; no bias \\
\hline $3^{\mathrm{a}}$ & $1974-1958$ & Optimal & None & Corallites parallel to surface; no bias \\
\hline $4 \mathrm{~A}$ & $1958-1952$ & Sub-optimal & Warm & $\begin{array}{l}\text { Corallites at an angle to the surface; scallop texture from angles of coral- } \\
\text { lites }\end{array}$ \\
\hline $4 \mathrm{~A}$ & $1951-1945$ & Sub-optimal & Warm & $\begin{array}{l}\text { Corallites at an angle to the surface; 1947-1952 low growth rate; re- } \\
\text { duced seasonality }\end{array}$ \\
\hline $4 \mathrm{~B}^{\mathrm{a}}$ & 1947-1936 & Optimal & None & $\begin{array}{l}\text { Corallites parallel to surface, } 1945-1947 \text { better orientation } \\
\text { than in slab 4A }\end{array}$ \\
\hline $4 \mathrm{~B}^{\mathrm{a}}$ & $1938-1933$ & Sub-optimal & None & $\begin{array}{l}\text { Corallites at an angle to the surface; 1936-1941 warm anomaly years } \\
\text { show normal seasonality and high growth rate }\end{array}$ \\
\hline $5^{\mathrm{a}}$ & $1933-1922$ & Optimal & None & Corallites parallel to surface; $1922-1928$ reduced seasonality \\
\hline 6 & $1921-1915$ & Sub-optimal & Warm & $\begin{array}{l}\text { 1915-1521 warm spikes shows slightly oblong corallites, yet normal } \\
\text { seasonality; switch from optimal to sub-optimal orientation }\end{array}$ \\
\hline $6^{\mathrm{a}}$ & $1915-1896$ & Optimal to sub-optimal & None & $\begin{array}{l}\text { Corallites mostly parallel to surface, small section with } \\
\text { corallites at slight angle }\end{array}$ \\
\hline $7^{\mathrm{a}}$ & $1897-1890$ & Optimal & None & Corallites parallel to surface \\
\hline 7 & $1887-1882$ & Optimal & Cool & Diagenesis detected between years $1882-1887$ \\
\hline $7^{\mathrm{a}}$ & $1881-1872$ & Sub-optimal & None & $\begin{array}{l}\text { Corallites at an angle to the surface; } 1872 \text { close to bioerosion track; } \\
1878-1880 \text { low seasonality, yet no effect }\end{array}$ \\
\hline 8 & $1872-1868$ & Sub-optimal & Cool & $\begin{array}{l}\text { Corallites at an angle to the surface; some corallites at almost } 90^{\circ} \text { angle; } \\
1868-1872 \text { below bioerosion track; } 1867-1871 \text { low seasonality }\end{array}$ \\
\hline 9 & $1860-1854$ & Sub-optimal & Warm & $\begin{array}{l}\text { Corallites at an angle to the surface; } 1854-1858 \text { low seasonality, less } \\
\text { winter samples }\end{array}$ \\
\hline 9 & $1856-1845$ & Sub-optimal & Warm & $\begin{array}{l}\text { Corallites parallel to surface; low seasonality with relatively } \\
\text { warm winter samples }\end{array}$ \\
\hline $9^{\mathrm{a}}$ & 1844-1831 & Optimal & None & $\begin{array}{l}\text { Corallites parallel to surface; only } 1831-1832 \text { corallites at } \\
\text { an angle to surface }\end{array}$ \\
\hline 10 & $1830-1827$ & Sub-optimal & Warm & Corallites at an angle to the surface; oblong orientation \\
\hline 10 & $1826-1823$ & Disorganized & Warm & $\begin{array}{l}\text { Corallites rotating at } 90^{\circ} \text { angle; low growth rate, seasonality reduced } \\
1823-1825 \text { with relatively warm winter samples }\end{array}$ \\
\hline $10^{\mathrm{a}}$ & $1822-1815$ & Optimal & None & $\begin{array}{l}\text { Corallites parallel to surface; low growth rate; reduced seasonality } \\
1818-1822 \text {, yet no effect on SST anomalies }\end{array}$ \\
\hline $11^{\mathrm{a}}$ & 1816-1806 & Sub-optimal & None & Corallites at an angle to the surface, yet no effect on SST anomalies \\
\hline $11^{\mathrm{a}}$ & $1807-1798$ & Sub-optimal & None & $\begin{array}{l}\text { Corallites at an angle to the surface in sub-optimal parts; corallites ro- } \\
\text { tating at } 90^{\circ} \text { angle near terminating fans (not sampled); three growth } \\
\text { axes with terminating fans in between (not sampled); } \\
1799-1807 \text { regular seasonality }\end{array}$ \\
\hline 11 & $1797-1792$ & Sub-optimal & Warm & Corallites at an angle to the surface \\
\hline 12 & $1795-1792$ & Disorganized & Warm & $\begin{array}{l}\text { Corallites rotating at } 90^{\circ} \text { angle; } 1792-1791 \text { long year, } \\
\text { more summer samples }\end{array}$ \\
\hline 12 & $1791-1784$ & Sub-optimal & Warm & $\begin{array}{l}\text { Corallites parallel to surface; } 1784-1787 \text { corallites at an angle to the } \\
\text { surface; } 1789-1794 \text { seasonality distorted }\end{array}$ \\
\hline 12 & $1781-1783$ & Disorganized & Warm & $\begin{array}{l}\text { Corallites rotating at } 90^{\circ} \text { angle; seasonality slightly distorted, appar- } \\
\text { ently more summer samples }\end{array}$ \\
\hline
\end{tabular}

${ }^{\mathrm{a}}$ Unbiased sampling tracks.

anomaly in the years 1916 to 1921 . Nevertheless, the extreme warm anomaly between 1916 and 1921 could be associated with an unidentified vital effect (Alpert et al., 2015). Interestingly, despite the potential influence of vital effects on the trend, the seasonality in this core section was well preserved.
This implies that seasonality can be captured robustly while absolute values and trends are potentially biased by vital effects. This adds confidence for the study of seasonality from fossil corals where vital effects are harder to distinguish from true variability due to the lack of SST data for verification. 
Table 3. Summary of sampling issues detected in core Cabri.

\begin{tabular}{lclll}
\hline Section & Year & Orientation & Bias & Notes \\
\hline 1 & $2007-2000$ & Sub-optimal & Warm & Corallites parallel to surface; yet no clear growth fans \\
$1^{\text {a }}$ & $1999-1992$ & Optimal & None & Corallites parallel to surface \\
$2^{\text {a }}$ & $1984-1992$ & Sub-optimal & None & Corallites at an angle to the surface; oblong corallites \\
$3^{\text {a }}$ & $1983-1968$ & Sub-optimal & None & Corallites parallel to surface; yet no clear growth fan \\
$4^{\text {a }}$ & $1967-1964$ & Sub-optimal & None & Corallites at an angle to the surface \\
$5^{\text {a }}$ & $1963-1958$ & Optimal & None & Corallites parallel to surface \\
$5^{\text {a }}$ & $1957-1954$ & Sub-optimal & None & Corallites at an angle to the surface \\
$5^{\text {a }}$ & $1953-1945$ & Optimal & None & Corallites parallel to surface \\
\hline
\end{tabular}

${ }^{a}$ Unbiased sampling tracks.
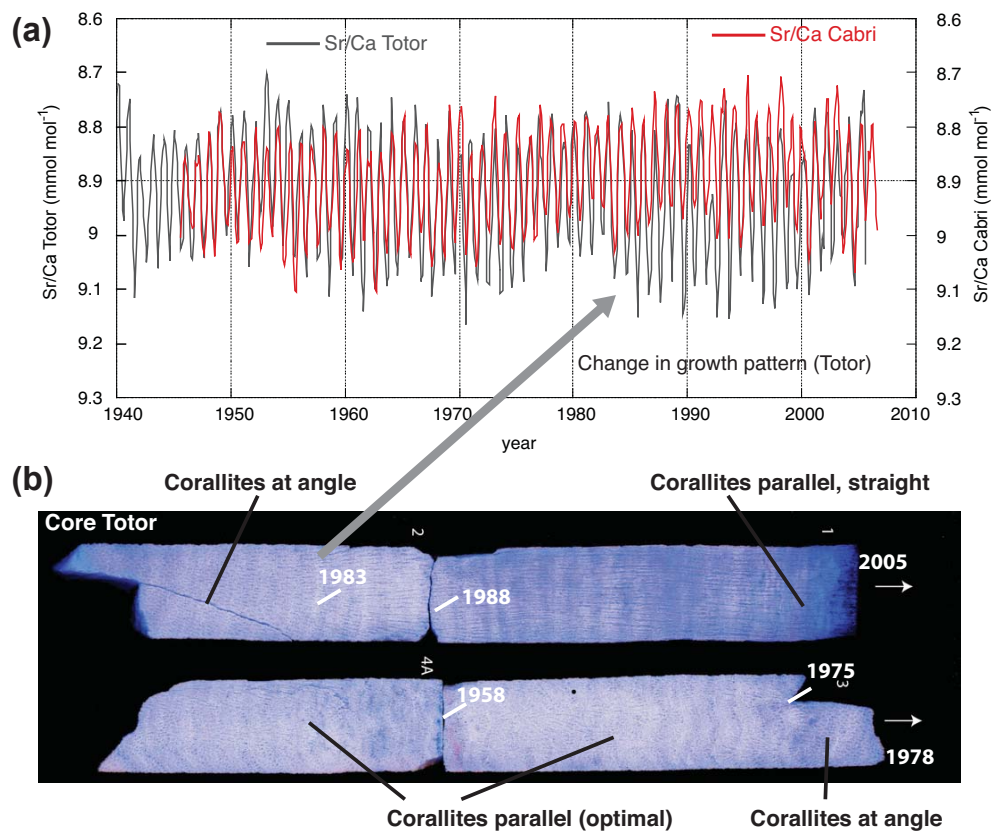

Figure 9. (a) Monthly interpolated Sr / Ca profiles for cores Cabri (red) and Totor (grey). (b) Images of core Totor (coloured blue) with orientation of corallites indicated. Years for core sections indicated on coral slab and grey arrow points to major change in growth pattern in the Totor core top section around the years 1983/84.

For the core tops between 1984 and 2005, Sr / Ca trends in cores Totor and Cabri deviate with Totor showing a statistically insignificant cooling trend, while Cabri shows a strong warming trend (Fig. 2). Our analysis of polyp growth revealed a change in growth pattern near the top of core Totor: the corallites form parallel, elongated rods of septa for the entire period 1984 to 2005 (Fig. 9). Cabri shows a normal growth pattern, with an optimal orientation of corallites at the core top between 1984 and 2006 (Fig. A5), with the exception of sub-optimal corallites in the period 2000 to 2006. The core top of the Totor coral skeleton has very low overall density compared to the pre-1984 record. The $\mathrm{Sr} / \mathrm{Ca}$ ratios show an increased seasonality, with colder winter values compared to core Cabri, while summer values are not affected. At first glance, the peculiar structure of the coral- lites in Totor would suggest optimal vertical growth of the corallites with the polyps clearly visible from the apex of the core slab. This structure is, however, clearly associated with high $\mathrm{Sr} / \mathrm{Ca}$ ratios and artificially cold SST anomalies. A similar growth pattern was found in a Porites lutea from St Marie Island off the east of Madagascar (core STM4 in Grove et al., 2013a). Grove et al. (2013a) ascribed the Sr / Ca trend difference between cores STM2 and STM4 to changes in coral growth and calcification; yet their results were not conclusive. Re-examination of core STM4 revealed that it also forms the parallel-elongated rods of septa in the core top, which was biased towards high $\mathrm{Sr} / \mathrm{Ca}$ ratios and therefore cold SST anomalies. STM4 also showed low densities in this core top section that agrees with low density in Totor. Inspection of various core sections in Totor and other coral 
cores revealed that similar elongated rods of septa (not sampled down core) are formed between neighbouring growth fans of septa. We propose that these parallel septa grow very fast in summer and winter, and therefore show weak density contrast with overall low skeletal density. Similar anomalously high $\mathrm{Sr} / \mathrm{Ca}$ values between adjacent fans of corallites were reported for Great Barrier Reef corals (see Fig. 4 in Alibert and McCulloch, 1997). Alibert and McCulloch (1997) suggested that less optimal growth conditions may result in smaller corallites and overall low skeletal density affecting $\mathrm{Sr} / \mathrm{Ca}$ ratios. We suggest that core tops from Porites sp. with similar parallel septa should be avoided for sampling since it can cause a cold bias in Sr / Ca-based SST reconstructions.

Overall, our test for sampling biases confirms the findings of De Long et al. (2012) to a large extent, and indicates that such analysis should accompany climate reconstructions from coral cores. Our results suggest that new cores need to be obtained from the Totor colony or other large Porites sp. in order to overcome the SST biases identified in the current record. The Cabri coral ( $>3.5 \mathrm{~m}$ in height) would be an ideal site since it provided an excellent and largely un-biased record of SST for the period 1945 to 2006. The 1907 dead surface was present, however, in three long cores drilled from the Cabri coral at different angles, which could undermine the SST reconstruction, for a few decades below the mortality event. The reason for the mortality event could not be determined.

\subsection{Trends and large-scale climate teleconnections since 1945 from core Cabri}

Based on our analysis of corallite orientations and diagenesis, we conclude that core Cabri provides a largely unbiased record to assess SST trends and interannual variability since 1945 . The Cabri time series recorded a higher SST rise $\left(1.38 \pm 0.41^{\circ} \mathrm{C}\right)$ than instrumental data between 1945 and 2006, which ranged between 0.61 and $0.86 \pm 0.15^{\circ} \mathrm{C}$. The trend in Cabri agrees with all SST datasets within $2 \sigma$, whereby the lower range of uncertainty for the Cabri trend estimates $\left(\sim 1^{\circ} \mathrm{C}\right)$ is in close agreements to trends from gridded SST datasets. Most of the accelerated warming trend in Cabri resulted from the recent 6 years where the orientation of the corallites was sub-optimal. We conclude that the SST trend in Cabri closely follows open ocean grid SST, which both indicate strong warming $\left(\sim 0.68-1{ }^{\circ} \mathrm{C}\right)$ of the south-central Indian Ocean over the past 60 years. Roxy et al. (2014) reported that during 1901-2012, the Indian Ocean warm pool warmed by $0.78^{\circ} \mathrm{C}$, while the western Indian Ocean $\left(5^{\circ} \mathrm{S}-10^{\circ} \mathrm{N}, 50-65^{\circ} \mathrm{E}\right)$ experienced anomalous warming of $1.28^{\circ} \mathrm{C}$ in summer SSTs. Our results for Cabri are therefore not unusual and are within the range of observed Indian Ocean SST trends (Annamalei et al., 2005; Alory and Meyers, 2007; Koll Roxy et al., 2014). The strong warming in the southern Indian Ocean trade wind belt could potentially alter the monsoon circulation, especially during the monsoon onset phase in austral autumn (March to May; Annamalei et al., 2005). Both our Cabri coral SST time series and SST products indicate the strongest warming for the March to May season (not shown). Rodrigues station precipitation is strongly positively correlated with SST between March and May. When precipitation is anchored over a warmer SWIO between March and May it can prevent the movements of the ITCZ towards the north and potentially disrupt the Asian monsoon onset (Annamalei et al., 2005).

The Cabri record also indicated that Rodrigues Island has negative correlations with the SIOD. Rodrigues Island is located at the westernmost edge of the northeastern flank of the SIOD that stretches from the south-central western Indian Ocean to the coast of western Australia. There is no other coral reef between Rodrigues Island and the west Australian coast that is able to track the SIOD. Rodrigues is therefore the only coral reef at which SST variability tracks the SIOD at its northeastern flank. The Ifaty corals off southwest Madagascar were shown to track the southwestern flank of the SIOD (Zinke et al., 2004). Our results suggest that a combination of corals off southwest Madagascar with longer records from Rodrigues could provide valuable records of past SIOD variability.

The Cabri coral SST reconstructions revealed a clear ENSO/PDO teleconnection pattern for mean annual and austral summer averages with positive correlations across the Indian Ocean in response to ENSO and PDO (Xie et al., 2016; Fig. 6 and 7; Tables S17-S19). The ENSO/PDO teleconnection was stable for the recent 60 years, yet appears strongest between 1971 and 2006 (Fig. 6c, f). The latter period is known for increased occurrence of El Niño events and a switch to a positive PDO phase up to 1999 (McPhaden et al., 2006). These results are in agreement with ENSO/PDO pattern correlations observed in other coral records from the southwestern Indian Ocean (Pfeiffer et al., 2004; Crüger et al., 2009). This is the first Indian Ocean coral SST reconstruction, however, that shows a clear Indian Ocean SST relationship with the PDO. Previous studies have shown only indirect links between the PDO and southwestern Indian Ocean sea level pressure and salinity (Crüger et al., 2009), hydrological balance (Zinke et al., 2008) and river runoff (Grove et al., 2013b). In addition, our record is the first $\mathrm{Sr} / \mathrm{Ca}$ record for the south-central Indian Ocean, which is currently the most reliable proxy for SST in corals. The only long record from this region of the Indian Ocean is a stable isotope record from La Réunion Island that mainly records salinity variations (Pfeiffer et al., 2004). The lack of correlation between the La Réunion and Cabri record is therefore not surprising and points to the need to develop $\mathrm{Sr} / \mathrm{Ca}$ time series for La Réunion. The St Marie Island Sr / Ca coral record shows reasonable agreement with Cabri, with the SST shift in the 1970s especially apparent in both records (Fig. 8). The St Marie Island record is, however, not well suited to track the wider trade wind belt variations. Therefore, our new proxy record from Rodrigues for the period between 1945 and 2006 
is a valuable addition to the sparse Indian Ocean coral proxy network. It also establishes that records from Rodrigues are well suited to study decadal climate teleconnections with the (extra)tropical Pacific and the wider Indian Ocean.

\section{Data availability}

Coral proxy data for comparison to our Rodrigues time series from the NOAA (2016) paleoclimate data archive are available at https://www.ncdc.noaa.gov/data-access/ paleoclimatology-data/datasets/coral-sclerosponge. Air temperatures have been recorded by the WMO weather station 61988 (name: Rodrigues, Mauritius) since 1951 and are available at http://climexp.knmi.nl/ (KNMI, 2016).

For sea surface temperature and night-time marine air temperature data please see ERSST4 (https://www.ncdc.noaa.gov/data-access/marineocean-data/ extended-reconstructed-sea-surface-temperature-ersst-v4) (Huang et al., 2016), HadSST3 (http://www.metoffice.gov. uk/hadobs/hadsst3/) (Kennedy et al., 2016), HadNMAT2 (http://www.metoffice.gov.uk/hadobs/hadnmat2/) (Kent et al., 2016), HadISST (http://www.metoffice.gov.uk/ hadobs/hadisst/) (Rayner et al., 2016a), HadMAT1 (http://www.metoffice.gov.uk/hadobs/mohmat/) (Rayner et al., 2016b), OI SST (http://www.esrl.noaa.gov/ $\mathrm{psd} /$ data/gridded/data.noaa.oisst.v2.html) (Reynolds et al., 2016a), AVHRSST (https://podaac.jpl.nasa.gov/ AVHRR-Pathfinder) (Reynolds et al., 2016b), ERSST3b (https://www.ncdc.noaa.gov/data-access/marineocean-data/ extended-reconstructed-sea-surface-temperature-ersst-v3b) (Smith et al., 2016) and AVHRSST (http://icoads.noaa. gov) (Woodruff et al., 2016). 


\section{Appendix A}

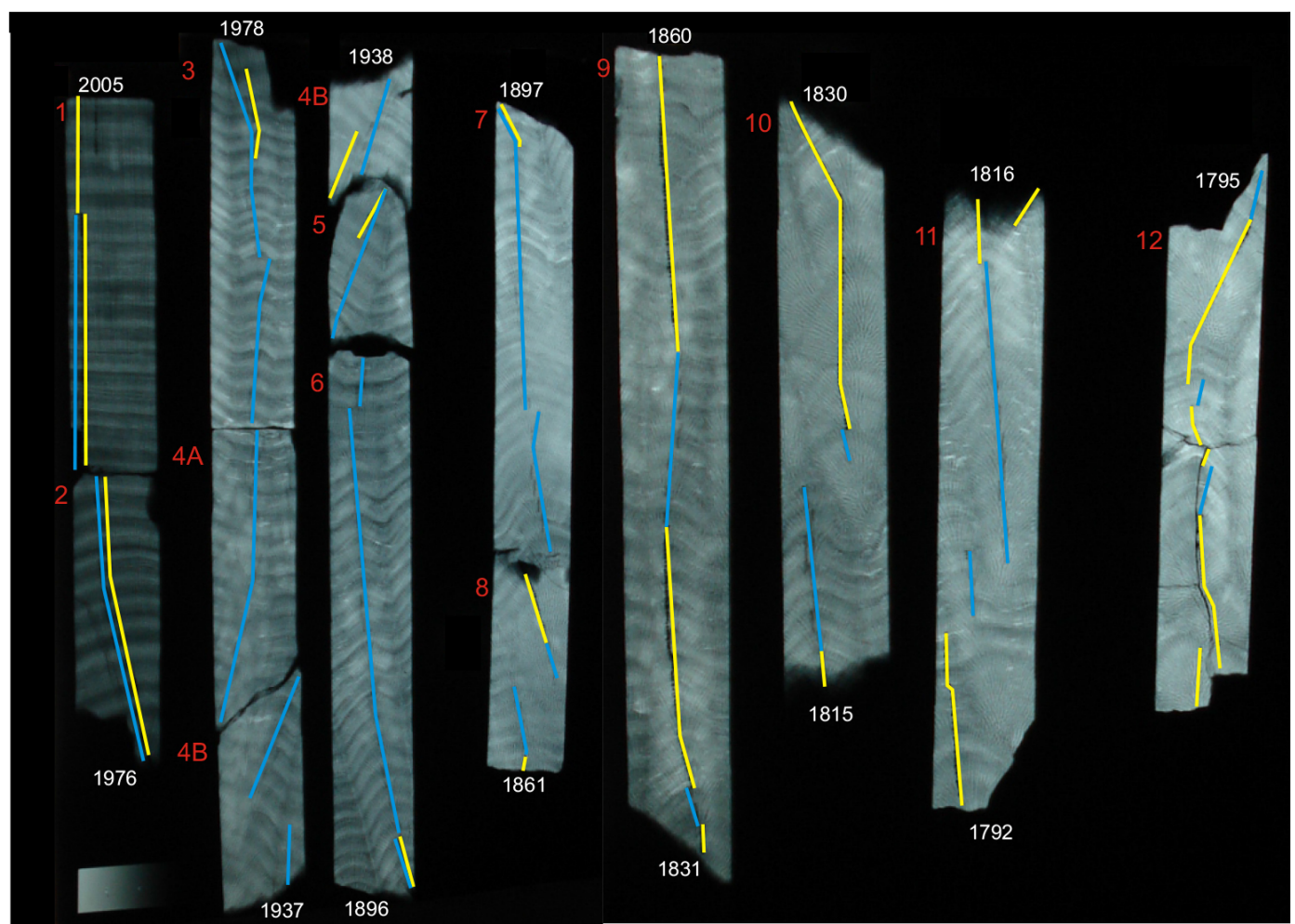

Figure A1. X-ray negative print for core sections of core Totor with sampling lines indicated. Blue lines indicate high-resolution sampling tracks. Yellow lines superimposed on blue lines indicate sampling at annual resolution for other purposes. Start or end years for each core section indicated.

Table A1. Statistics of various sea surface temperature (SST) products and air temperature for Rodrigues with $1 \sigma$ standard deviations in brackets for the period 2002 to 2006 (period with in situ SST data). ST $=1 \sigma$ standard deviation over all years. All units in ${ }^{\circ} \mathrm{C}$.

\begin{tabular}{lllll}
\hline & $\begin{array}{l}\text { SST in situ } \\
\text { 2002-2006 }\end{array}$ & $\begin{array}{l}\text { AVHRR SST } \\
\text { 2002-2006 }\end{array}$ & $\begin{array}{l}\text { ERSST } \\
\text { 2002-2006 }\end{array}$ & $\begin{array}{l}\text { Air temp. } \\
\text { 2002-2006 }\end{array}$ \\
\hline Mean annual & $25.49(0.24)$ & $25.4(0.11)$ & $25.57(0.3)$ & $27.49(0.31)$ \\
Maximum & $28.6(0.5)$ & $28.65(0.44)$ & $28.29(0.4)$ & $31.2(0.62)$ \\
Minimum & $22.4(0.27)$ & $22.75(0.21)$ & $23.15(0.13)$ & $24.2(0.44)$ \\
Seasonal range & $6.22(0.68)$ & $5.9(0.58)$ & $5.14(0.39)$ & $7.0(0.79)$ \\
ST & 2.14 & 1.78 & 1.69 & 2.07 \\
\hline
\end{tabular}





Figure A2. X-ray negative print for core sections of core Cabri with sampling lines (milling holes) indicated. Start or end years for each core section indicated. Note the dead surface before 1907 that is most probably related to a past coral bleaching event.

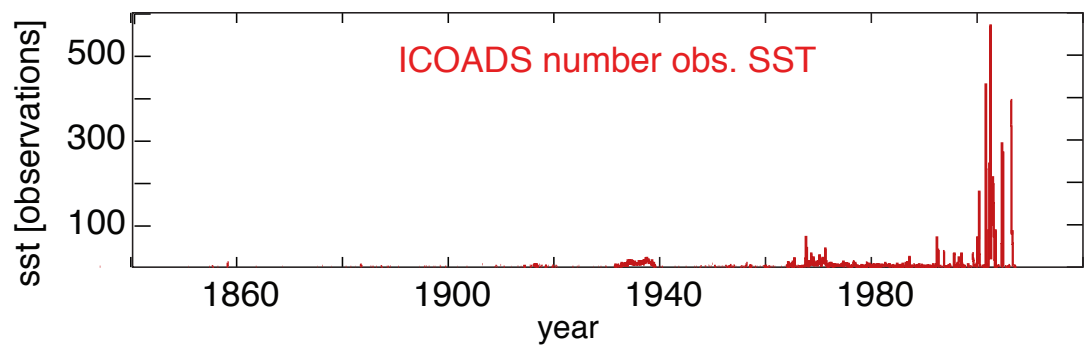

Figure A3. Number of SST observations in the grid box surrounding Rodrigues in the ICOADS database. Note the extremely sparse observations, even in recent years (van Oldenborgh and Burgers, 2005). 


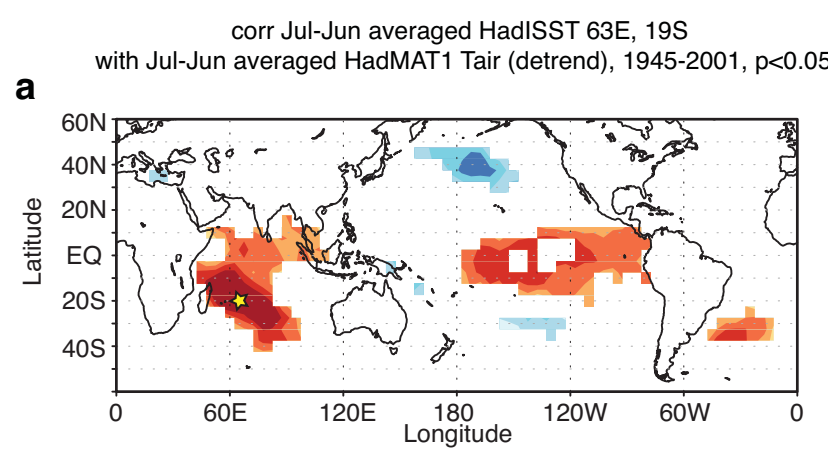

corr Jul-Jun averaged Cabri SST

b with Jul-Jun averaged HadMAT1 Tair (detrend), 1945-2001, p<0.05

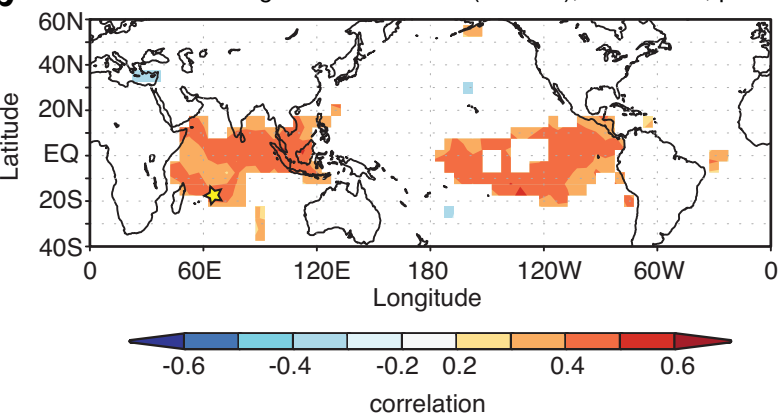

Figure A4. Spatial correlations of mean annual HadMAT1 air temperature anomalies between 1945 and 2001 relative to 1961-1990 with (a) HadISST for Rodrigues, and (b) Cabri SST. Only correlations with $p<0.05$ are coloured. Computed at KNMI Climate Explorer (van Oldenborgh and Burgers, 2005). $Y$ axis: latitude, $X$ axis: longitude.

Table A2. Linear regression of coral Sr / Ca with (a) in situ SST 2002-2005/6, (b) ERSSTv.3 (Smith et al., 2008) 1997-2005/6, (c) AVHRR SST NOAA Coral Reef watch data 2000-2005/6 and (d) monthly Sr / Ca with AVHRR SST (Reynolds et al., 2007) for the period 1982 to 2005.

\begin{tabular}{llll}
\hline & Regression equation & $r^{2}$ & $p$ \\
\hline (a) Max-min & & & \\
\hline Totor & $\mathrm{Sr} / \mathrm{Ca}=-0.0439( \pm 0.004) * \mathrm{SST}+10.032( \pm 0.10)$ & 0.97 & $<0.001$ \\
Cabri & $\mathrm{Sr} / \mathrm{Ca}=-0.0384( \pm 0.005) * \mathrm{SST}+9.861( \pm 0.12)$ & 0.89 & $<0.001$ \\
\hline (b) Max-min & & & \\
Totor & $\mathrm{Sr} / \mathrm{Ca}=-0.0638( \pm 0.004) * \mathrm{SST}+10.566( \pm 0.09)$ & 0.95 & $<0.001$ \\
Cabri & $\mathrm{Sr} / \mathrm{Ca}=-0.0507( \pm 0.004) * \mathrm{SST}+10.179( \pm 0.10)$ & 0.90 & $<0.001$ \\
\hline (c) Max-min & & & \\
Totor & $\mathrm{Sr} / \mathrm{Ca}=-0.0531( \pm 0.004) * \mathrm{SST}+10.271( \pm 0.11)$ & 0.96 & $<0.001$ \\
Cabri & $\mathrm{Sr} / \mathrm{Ca}=-0.0441( \pm 0.005) * \mathrm{SST}+10.012( \pm 0.13)$ & 0.88 & $<0.001$ \\
\hline (d) Monthly & & & \\
Totor & $\mathrm{Sr} / \mathrm{Ca}=-0.0522( \pm 0.003) * \mathrm{SST}+10.272( \pm 0.08)$ & 0.79 & $<0.001$ \\
Cabri & $\mathrm{Sr} / \mathrm{Ca}=-0.0419( \pm 0.003) * \mathrm{SST}+9.95( \pm 0.07)$ & 0.87 & $<0.001$ \\
\hline
\end{tabular}




\section{The Supplement related to this article is available online at doi:10.5194/bg-13-5827-2016-supplement.}

Acknowledgements. The coral paleoclimate work was supported as part of the SINDOCOM grant under the Dutch NWO program "Climate Variability", grant 854.00034/035. Additional support comes from the NWO ALW project CLIMATCH, grant 820.01.009, and the Western Indian Ocean Marine Science Association through the Marine Science for Management program under grant MASMA/CC/2010/02. We thank the team of SHOALS Rodrigues for their excellent support in fieldwork logistics and in the organization of the research and CITES permits. We would also like to thank the Rodrigues Assembly and the Mauritius Ministry for Fisheries for granting the research and CITES permits. A Senior Curtin Fellowship in Western Australia, and an Honorary Fellowship with the University of the Witwatersrand, South Africa, supported J. Zinke. Bouke Lacet and Wynanda Koot (VUA) helped cut the core slabs and prepared the thin sections. Janice Lough and Eric Matson (AIMS) provided skilled technical support for coral core densitometry measurements and data processing. We thank Dieter Garbe-Schönberg for assistance with the ICP-OES measurements.

Edited by: A. Shemesh

Reviewed by: two anonymous referees

\section{References}

Alibert, C. and McCulloch M. T.: Strontium/calcium ratios in modern Porites corals from the Great Barrier Reef as a proxy for sea surface temperature: calibration of the thermometer and monitoring of ENSO, Paleoceanography, 12, 345-363, 1997.

Alory, G. and Meyers, G.: Warming of the Upper Equatorial Indian Ocean and Changes in the Heat Budget (1960-99), J. Climate, 22, 93-113, 2009.

Alpert, A. E., Cohen, A. L., Oppo, D. W., DeCarlo, T. M., Gove, J. M., and Young, C. W.: Comparison of equatorial Pacific sea surface temperature variability and trends with $\mathrm{Sr} / \mathrm{Ca}$ records from multiple corals, Paleoceanography, 31, 252-262, 2016.

Annamalai, H., Liu, P., and Xie, S.-P.: Southwest Indian Ocean SST Variability: Its Local Effect and Remote Influence on Asian Monsoons, J. Climate, 18, 4150-4167, 2005.

Behera, S. K. and Yamagata, T.: A dipole mode in the tropical Indian Ocean. Geophys. Res. Lett., 28, 327-330, 2001.

Carricart-Ganivet, J. P. and Barnes D. J.: Densitometry from digitized images of X-radiographs: methodology for measurement of coral skeletal density, J. Exp. Mar. Biol. Ecol., 344, 67-72, 2007.

Charles, C. D., Hunter, D. E., and Fairbanks R. G.: Interaction between the ENSO and the Asian Monsoon in a coral record of tropical climate, Science, 277, 925-928, 1997.

Cobb, K. M., Charles, C. D., and Hunter D. E.: A central tropical pacific coral demonstrates pacific, Indian, and Atlantic decadal climate connections, Geophys. Res. Lett., 28, 2209-2212, 2001.

Cole, J. E., Dunbar, R. B., McClanahan, T. R., and Muthiga N. A.: Tropical Pacific forcing of decadal SST variability in the Western
Indian Ocean over the past two centuries, Science, 287, 617-619, 2000.

Corrège, T.: Sea surface temperature and salinity reconstruction from coral geochemical tracers. Palaeogeogr. Palaeocl., 232, 408-428, 2006.

Crüger, T., Zinke, J., and Pfeiffer M.: Patterns of Pacific decadal variability recorded by Indian Ocean corals, Int. J. Earth Sci. 98 , doi:10.1007/s00531-008-0324-1, 2009.

DeLong, K. L., Quinn, T. M., Taylor, F. W., Shen, C.-C., and Lin, K.: Improving coral-base paleoclimate reconstructions by replicating 350 years of coral $\mathrm{Sr} / \mathrm{Ca}$ variations, Palaeogeogr. Palaeocl., 373, 6-24, 2012.

Deser, C., Phillips, A. S., and Hurrell, J. W.: Pacific Interdecadal climate variability: linkages between the tropics and the North Pacific during boreal winter since 1900, J. Climate, 17, 31093124, 2004.

De Villiers, S., Sheng, G. T., and Nelson, B. K.: The Sr /Catemperature relationship in coralline aragonite: Influence of variability in $(\mathrm{Sr} / \mathrm{Ca})$ seawater and skeletal growth parameters, Geochim. Cosmochim. Ac., 58, 197-208, 1994.

Felis, T. and Paetzold, J.: Climate records from corals, in: Marine Science Frontiers for Europe, edited by: Wefer, G., Lamy, F., and Mantoura, F., Spinger, Berlin Heidelberg, Germany, New York, USA, Tokyo, Japan, 11-27, 2003.

Funk, C., Dettinger, M. D., Michaelsen, J. C., Verdin, J. P., Brown, M. E., Barlow, M., and Hoell, A.: Warming of the Indian Ocean threatens eastern and southern African food security but could be mitigated by agricultural development, P. Natl. Acad. Sci. USA, 105, 11081-11086, 2008.

Gagan, M. K., Dunbar, G. B., and Suzuki, A.: The effect of skeletal mass accumulation in Porites on coral $\mathrm{Sr} / \mathrm{Ca}$ and d180 paleothermometry, Paleoceanography 27, PA1203, doi:10.1029/2011PA002215, 2012.

Grove, C. A., Kasper, S., Zinke, J., Pfeiffer, M., Garbe-Schönberg, D., and Brummer, G.-J. A.: Confounding effects of coral growth and high SST variability on skeletal $\mathrm{Sr} / \mathrm{Ca}$ : Implications for coral paleothermometry, Geochem., Geophys. Geosyst., 14, 1277-1293, doi:10.1002/ggge.20095, 2013a.

Grove, C. A., Zinke, J., Peeters, F., Park, W., Scheufen, T., Kasper, S., Randriamanantsoa, B., McCulloch, M. T., and Brummer, G.-J. A.: Madagascar corals reveal a multidecadal signature of rainfall and river runoff since 1708, Clim. Past, 9, 641-656, doi:10.5194/cp-9-641-2013, 2013b.

Hardman, E. R., Meunier, M. S., Turner, J. R., Lynch, T. L., Taylor, M., and Klaus, R.: The extent of coral bleaching in Rodrigues, J. Nat. Hist., 38, 3077-3089, 2004.

Hardman, E. R., Stampfli, N. S., Hunt, L., Perrine, S., Perry, A., and Raffin, J. S.: The Impacts of coral bleaching in Rodrigues, Western Indian Ocean, Atoll Research Bulletin, 555, 110, doi:10.5479/si.00775630.555.1, 2008.

Helmle, K. P., Dodge, R. E., Swart, P. K., Gledhill, D. K., and Eakin, C. M.: Growth rates of Florida corals from 1937 to 1996 and their response to climate change, Nat. Commun., 2, 215, doi:10.1038/ncomms1222, 2011.

Hendy, E. J., Gagan, M. K., Lough, J. M., McCulloch, M., and deMenocal P. B.: Impact of skeletal dissolution and secondary aragonite on trace element and isotopic climate proxies in Porites corals, Paleoceanography, 22, PA4101, doi:10.1029/2007PA001462, 2007. 
Hoell, A., Funk, C., Zinke, J., and Harrison, L.: Modulation of the Southern Africa precipitation response to the El Niño Southern Oscillation by the subtropical Indian Ocean Dipole, Clim. Dynam., doi:10.1007/s00382-016-3220-6, 2016.

Huang, B., Banzon, V. F., Freeman, E., Lawrimore, J., Liu, W., Peterson, T. C., Smith, T. M, Thorne, P. W., Woodruff, S. D., and Zhang, H.-M: Extended Reconstructed Sea Surface Temperature version 4 (ERSST.v4): Part I, Upgrades and intercomparisons, J. Climate, 28, 911-930, doi:10.1175/JCLI-D-14-00006.1, 2015.

Huang, B., Banzon, V. F., Freeman, E., Lawrimore, J., Liu, W., Peterson, T. C., Smith, T. M., Thorne, P. W., Woodruff, S. D., and Zhang, H.-M.: ERSST4, available at: https://www.ncdc.noaa.gov/data-access/marineocean-data/ extended-reconstructed-sea-surface-temperature-ersst- $v 4$, last access: 21 October 2016.

Jones, P.: The Reliability of Global and Hemispheric Surface Temperature Records, Adv. Atmos. Sci., 33, 269-282, 2016.

Kaplan, A., Cane, M. A., Kushnir, Y., Clement, A. C., Blumenthal, M. B., and Rajagopalan, B.: Analyses of global sea surface temperature 1856-1991, J. Geophys. Res., 103, 18567-18589, 1998.

Kennedy, J. J., Rayner, N. A., Smith, R. O., Saunby, M., and Parker, D. E.: Reassessing biases and other uncertainties in sea-surface temperature observations since 1850 part 1: measurement and sampling errors, J. Geophys. Res., 116, D14103, doi:10.1029/2010JD015218, 2011.

Kennedy, J. J., Rayner, N. A., Smith, R. O., Saunby, M., and Parker, D. E.: HadSST3, available at: http://www.metoffice.gov. uk/hadobs/hadsst3/, last access: 21 October 2016.

Kent, E. C., Rayner, N. A., Berry, D. I., Saunby, M., Moat, B. I., Kennedy, J. J., and Parker, D. E.: Global analysis of night marine air temperature and its uncertainty since 1880: the HadNMAT2 Dataset, J. Geophys. Res., 118, 1281-1298, doi:10.1002/jgrd.50152, 2013.

Kent, E. C., Rayner N. A., Berry D. I., Saunby M., Moat B. I., Kennedy J. J., and Parker, D. E.: HadNMAT2, available at: http://www.metoffice.gov.uk/hadobs/hadnmat2/, last access: 21 October 2016.

KNMI: Coral proxy data, available at: http://climexp.knmi.nl/, last access: 21 October 2016.

Koll Roxy, M., Ritika, K., Terray, P., and Masson, S.: The curious case of Indian Ocean warming, J. Climate, 27, 8501-8509, 2014.

Koll Roxy, M., Ritika, K., Terray, P., and Masson, S.: The curious case of Indian Ocean warming, J. Climate 27, 8501-8509, doi:10.1175/JCLI-D-14-00471.1, 2014.

Krishnan, P. and Sugi, M.: Pacific decadal Oscillation and variability of the Indian summer monsoon rainfall, Clim. Dynam., 21, 233-242, 2003.

Lee, S.-K., Park, W., Baringer, M. O., Gordon, A. L., Huber, B., and Liu, Y.: Pacific origin of the abrupt increase in Indian Ocean heat content during the warming hiatus, Nat. Geosci., 8, 445449, 2015.

Lynch, T. L., Meunier, M. S., Hooper, T. E. J., Blais, F. E. I., Raffin, J. S. J, Perrine, S., Félicité, N., Lisette, J., and Grandcourt, J. W.: Annual report of benthos, reef fish and invertebrate surveys for Rodrigues 2002, Shoals Rodrigues report, 30 pp., 2002.

Mantua, N. J., Hare, S. R., Zhang, Y., Wallace, J. M., and Francis, R. C.: A Pacific decadal climate oscillation with impacts on salmon, B. Am. Meteorol. Soc., 78, 1069-1079, 1997.
Mart, Y.: The tectonic setting of the Seychelles, Mascarene and Amirante plateaus in the Western Equatorial Indian ocean, Mar. Geol., 79, 261-274, 1988.

McGregor, H. V. and Abram, N. J.: Images of diagenetic textures in Porites corals from Papua New Guinea and Indonesia, Geochem. Geophy. Geosy., 9, 1-17, doi:10.1029/2008GC002093, 2008.

McGregor, H. V. and Gagan, M. K.: Diagenesis and geochemistry of Porites corals from Papua New Guinea: implications for paleoclimate reconstruction, Geochim. Cosmochim. Acta, 67, 2147 2156, 2003.

McPhaden, M. J., Zebiak, S. E., and Glantz, M. H.: ENSO as an Integrating Concept in Earth Science, Science, 314, 1740-1745, 2006.

Meehl, G. A. and Hu, A.: Megadroughts in the Indian Monsoon Region and Southwest North America and a mechanism for associated Multidecadal Pacific Sea Surface Temperature Anomalies, J. Climate, 19, 1605-1623, 2006.

Nakamura, N., Kayanne, H., Iijima, H., McClanahan, T. R., Behera, S. K., and Yamagata, T.: Mode shift in the Indian Ocean climate under global warming stress, Geophys. Res. Lett., 36, L23708, doi:10.1029/2009GL040590, 2009.

New, A. L., Stansfield, K., Smythe-Wright, D., Smeed, D. A., Evans, A. J., and Alderson, S. G.: Physical and biochemical aspects of the flow across the, Mascarene Plateau in the Indian Ocean, Philos. T. R. Soc., 363, 151-168, 2005.

New, A. L., Alderson, S. G., Smeed, D. A., and Stansfield, K. L.: On the circulation of water masses across the Mascarene Plateau in the South Indian Ocean, Deep-Sea Res. Pt. I, 54, 42-74, 2007.

NOAA: WMO weather station 61988 air temperatures, available at: https://www.ncdc.noaa.gov/data-access/paleoclimatology-data/ datasets/coral-sclerosponge, last access: 21 October 2016.

Nurhati, I. S., Cobb, K. M., and Lorenzo E. D. Decadal-Scale SST and Salinity Variations in the Central Tropical Pacific: Signatures of Natural and Anthropogenic Climate Change. J. Climate, 24, 3294-3308, 2011.

Paillard, D., Labeyrie, L., and Yiou, P.: Macintosh program performs time series analysis, Eos Trans AGU, 77, p. 379, 1996

Pfeiffer, M. and Dullo, W.-C.: Monsoon-induced cooling of the western equatorial Indian Ocean as recorded in coral oxygen isotopes records from the Seychelles covering the period 1840-1994 AD, Quaternary Sci. Rev., 25, 993-1009, 2006.

Pfeiffer, M., Timm, O., and Dullo, W.-C.: Oceanic forcing of interannual and multidecadal climate variability in the southwestern Indian Ocean: Evidence from a 160 year coral isotopic record (La Reunion, 50 E, 21 S), Paleoceanography, 19, PA4006, doi:10.1029/2003PA000964, 2004.

Pfeiffer, M., Dullo, W.-C., Zinke, J., and Garbe-Schoenberg, D.: Three monthly coral $\mathrm{Sr} / \mathrm{Ca}$ records from the Chagos Archipelago covering the period of 1950-1995 AD: reproducibility and implications for quantitative reconstructions of sea surface temperature variations, Int. J. Earth Sci., 98, 53-66, doi:10.007/s00531-00008-00326-z, 2009.

Rayner, N. A., Parker, D. E., Horton, E. B., Folland, C. K., Alexander, L. V., Rowell, D. P., Kent, E. C., and Kaplan A.: Global analyses of sea surface temperature, sea ice, and night marine air temperature since the late nineteenth century, J. Geophys. Res., 108, 4407, doi:10.1029/2002JD002670, 2003.

Rayner, N. A., Parker, D. E., Horton, E. B., Folland, C. K., Alexander, L. V., Rowell, D. P., Kent, E. C., and Kaplan, A.: HadISST, 
available at: http://www.metoffice.gov.uk/hadobs/hadisst/, last access: 21 October 2016a.

Rayner, N. A., Parker, D. E., Horton, E. B., Folland, C. K., Alexander, L. V., Rowell, D. P., Kent, E. C., and Kaplan, A.: HadMAT1, available at: http://www.metoffice.gov.uk/hadobs/mohmat/, last access: 21 October 2016 b.

Reason, C. J. C.: Subtropical Indian Ocean SST dipole events and southern African rainfall, Geophys. Res. Lett., 28, 2225-2227, 2001.

Reynolds, R. W., Rayner, N. A., Smith, T. M., Stokes, D. C., and Wang W.: An improved in situ and satellite SST analysis for climate, J. Climate, 15, 1609-1625, 2002.

Reynolds, R. W., Smith, T. M., Liu, C., Chelton, D. B., Casey, K. S., and Schlax, M. G.: Daily high-resolution blended analyses for sea surface temperature, J. Climate, 20, 5473-5496, 2007.

Reynolds, R. W., Rayner, N. A., Smith, T. M., Stokes, D. C., and Wang, W.: OI SST, available at: http://www.esrl.noaa.gov/ psd/data/gridded/data.noaa.oisst.v2.html, last access: 21 October $2016 \mathrm{a}$.

Reynolds, R. W., Smith, T. M., Liu, C., Chelton, D. B., Casey, K. S., and Schlax, M. G.: AVHRSST, available at: https://podaac. jpl.nasa.gov/AVHRR-Pathfinder, last access: 21 October $2016 \mathrm{~b}$.

Sayani, H. R., Cobb, K. M., Cohen, A. L., Crawford Elliott, W., Nurhati, I. S., Dunbar, R. B., Rose, K. A., and Zaunbrecher, L. K.: Effects of diagenesis on paleoclimate reconstructions from modern and young fossil corals, Geochim. Cosmochim. Ac., 75, 6361-6373, 2011.

Schott, F. A. and McCreary, J. P.: The monsoon circulation of the Indian Ocean, Prog. Oceanogr., 51, 1-123, 2001.

Schrag, D. P.: Rapid analyses of high-precision $\mathrm{Sr} / \mathrm{Ca}$ ratios in corals and other marine carbonates, Paleoceanography, 14, 2, $97-$ $102,1999$.

Sheppard, C. R. C.: Predicted recurrences of mass coral mortality in the Indian Ocean. Nature, 425, 294-297, 2003.

Smith, T. M., Reynolds, R. W., Peterson, T. C., and Lawrimore, J.: Improvements to NOAA's historical merged land-ocean surface temperature analysis (1880-2006), J. Climate, 21, 2283-2296, 2008.

Smith, T. M., Reynolds, R. W., and Peterson, T. C.: available at: ERSST3b, https://www.ncdc.noaa.gov/dataaccess/marineocean-data/, last access: 21 October 2016b.

Smodej, J., Reuning, L., Wollenberg, U., Zinke, J., Pfeiffer, M., and Kukla, P. A.: Two-dimensional X-ray diffraction as a tool for the rapid, nondestructive detection of low calcite quantities in aragonitic corals, Geochem. Geophy. Geosy., 16, 3778-3788, doi:10.1002/2015GC006009, 2015.
Tokinaga, H., Xie, S. P., Deser, C., Kosaka, Y., and Okumura, Y. M.: Slowdown of the Walker circulation driven by tropical IndoPacific warming, Nature, 491, 439-444, 2012.

Trouet, V. and van Oldenborgh, G. J.: KNMI Climate Explorer: a web-based research tool for high-resolution paleoclimatology, Tree Ring Research, 69, 3-13, 2013.

Turner, J. and Klaus, R.: Coral reefs of the Mascarenes, Western Indian Ocean, Philos. T. R. Soc., 363, 229-250, 2005.

van Oldenborgh, G. J. and Burgers, G.: Searching for decadal variations in ENSO precipitation teleconnections, Geophys. Res. Lett., 32, L15701, doi:10.1029/2005GL023110, 2005.

Woodruff, S. D., Worley, S. J., Lubker, S. J., Ji, Z., Freeman, J. E., Berry, D. I., Brohan, P., Kent, E. C., Reynolds, R. W., Smith, S. R., and Wilkinson, C: ICOADS Release 2.5: Extensions and enhancements to the surface marine meteorological archive, Int. J. Climatol., 31, 951-967, 2011.

Woodruff, S. D., Worley, S. J., Lubker, S. J., Ji, Z., Freeman, J. E., Berry, D. I., Brohan, P., Kent, E. C., Reynolds, R. W., Smith, S. R., and Wilkinson, C.: ICOADS, available at: http://icoads.noaa. gov, last access: 21 October 2016.

Xie, S.-P., Kosaka Y., Du Y., Hu K. M., Chowdary J. S., and Huang G.: Indo-western Pacific ocean capacitor and coherent climate anomalies in post-ENSO summer: A review, Adv. Atmos. Sci., 33, 411-432, 2016.

Zinke, J., Dullo, W.-C., Heiss, G. A., and Eisenhauer, A.: ENSO and subtropical dipole variability is recorded in a coral record off southwest Madagascar for the period 1659 to 1995, Earth Planet. Sc. Lett., 228, 177-197, 2004.

Zinke, J., Timm, O., Pfeiffer, M., Dullo, W.-C., Kroon, D., and Thomassin, B. A.: Mayotte coral reveales hydrological changes in the western Indian between 1865 to 1994, Geophys. Res. Lett., 35, L23707, doi:10.1029/2008GL035634, 2008.

Zinke, J., Pfeiffer, M., Timm, O., Dullo, W.-C., and Brummer, G. J. A.: Western Indian Ocean marine and terrestrial records of climate variability: a review and new concepts on land-ocean interaction since A.D. 1660. Int. J. Earth Sci. 98, 115-133, doi:10.1007/s00531-008-0365-5, 2009.

Zinke, J., Pfeiffer, M., Park, W., Schneider, B., Reuning, L., Dullo, W.-Chr., Camoin, G. F., Mangini, A., Schroeder-Ritzrau, A., Garbe-Schönberg, D. and Davies, G. R.: Seychelles coral record of changes in sea surface temperature bimodality in the western Indian Ocean from the Mid-Holocene to the present, Clim. Dynam., 43, 689-708, 2014. 